\title{
Are Foreign IT Workers Cheaper? U.S. Visa Policies and Compensation of Information Technology Professionals
}

\author{
Sunil Mithas, Henry C. Lucas, Jr. \\ Robert H. Smith School of Business, University of Maryland, College Park, Maryland 20742 \\ \{smithas@rhsmith.umd.edu, hlucas@rhsmith.umd.edu\}
}

\begin{abstract}
$\mathrm{T}_{\mathrm{s}, \mathrm{sen}}^{\mathrm{n}}$ he use of $\mathrm{H}-1 \mathrm{~B}$ and other work visas to hire foreign information technology (IT) professionals in the United States has attracted significant controversy and policy debates. On one hand, hiring high-skill foreign IT professionals on work visas can be advantageous for U.S. firms and the overall economy. On the other hand, high-skill immigration can adversely impact the wages of foreign and American IT professionals. This study uses data on skills and compensation of more than 50,000 IT professionals in the United States over the period 2000-2005 to study patterns in compensation of foreign and American IT professionals to inform these debates. Contrary to the popular belief that foreign workers are a cheap source of labor for U.S. firms, we find that after controlling for their human capital attributes, foreign IT professionals (those without U.S. citizenship and those with $\mathrm{H}-1 \mathrm{~B}$ or other work visas) earn a salary premium when compared with IT professionals with U.S. citizenship. The salary premiums for non-U.S. citizens and for those on work visas fluctuate in response to supply shocks created by the annual caps on new H-1B visas. Setting lower and fully utilized annual caps results in higher salary premiums for non-U.S. citizens and those with work visas. We discuss implications of this study for crafting informed visa- and immigration-related policies by the U.S. government, for staffing practices of firms, and for human capital investments by IT professionals.

Key words: IT professionals; high-skill immigration; H-1B; work visa; managing IT resources; compensation; IT human capital; globalization

History: Received June 26, 2008; accepted October 3, 2009, by Sandra Slaughter, information systems.

Published online in Articles in Advance March 23, 2010.
\end{abstract}

\section{Introduction}

The globalization of work is a two-way street. Whereas one aspect of globalization relates to outward mobility of work to foreign workers at remote locations as reflected in outsourcing or offshoring of business processes and services (Apte et al. 2008, Carmel and Agarwal 2002, DiRomulado and Gurbaxani 1998, Han et al. 2010, Lacity et al. 2003, Mithas 2008, Mithas and Whitaker 2007, Ramasubbu et al. 2008b, Rottman and Lacity 2004), yet another aspect of globalization relates to the inward mobility of foreign workers who are immigrants or on a work visa. The United States admits more than one million immigrants every year, and although a large percentage of these workers have significantly lower skills than native workers (Borjas 2001), some immigrant workers, particularly from Europe and Asia, are highly skilled. In addition to immigrants, temporary work visa programs such as H-1B and L1 allow firms to bring foreign professionals into the United States for limited periods of time to overcome the shortage of skilled and qualified professionals to design and create innovative products and services for global markets (Thibodeau
2008). Although global mobility of work (Davis et al. 2006, King and Torkzadeh 2008, Oshri et al. 2007) and organization of global information technology (IT) function (Ives and Jarvenpaa 1991, Jarvenpaa and Ives 1993) have received significant attention in the information systems literature, the mobility of workers across country borders, particularly high-skill IT professionals, has received little research. ${ }^{1}$

Among high-skill workers, IT professionals who create the IT infrastructure to support critical business processes of firms (Ang and Slaughter 2000, Bartol and Aspray 2006, Ferratt et al. 2005, Harter and Slaughter 2003, Josefek and Kauffman 2003, Slaughter et al. 2007) are particularly susceptible to the forces of globalization. Arguably, because many ITrelated jobs also involve high information intensity and often few requirements for physical presence, these jobs are amenable to global disaggregation and

\footnotetext{
${ }^{1}$ In contrast to this study, which focuses on mobility across country boundaries, other studies (e.g., Ang and Slaughter 2000, Slaughter et al. 2007) discuss mobility of workers within a firm, across work settings and organizational contexts.
} 
can be performed remotely or offshore (Apte and Mason 1995). At the same time, interdependence of activities, the need for customer contact, and the difficulties involved in transferring tacit knowledge of customers and developers across geographic locations make it necessary to deploy some IT resources onsite (Espinosa et al. 2006, 2007; Ramasubbu et al. $2008 \mathrm{~b})$. Because of the presumed shortage of such highly skilled IT professionals in the United States (see Agarwal and Ferratt 1999, Lewin et al. 2009, U.S. Department of Commerce 1997), many U.S. and global firms hire foreign IT professionals on work visas to perform boundary spanning and related roles to coordinate the development of IT artifacts in a distributed environment.

Whereas the demand for foreign IT professionals depends on economic conditions and IT-producing or IT-consuming sectors of the economy, the supply of foreign professionals is limited by legislative actions and federal policies. One of the significant ways in which Congress regulates and determines the supply of human capital to technology- and knowledgeproducing sectors of the economy is by setting work visa caps for the entry of new foreign professionals in the United States. There is a need for care in establishing visa caps because setting them too low may constrain domestic industries and lead to the flight of such industries to offshore locations. For example, Microsoft opened a complex in Canada for 150 foreign professionals that it could not bring to the United States due to restrictive $\mathrm{H}-1 \mathrm{~B}$ visa caps in 2007 (Whoriskey 2008). Conversely, setting the annual caps too high can lead to politically sensitive concerns about protecting American jobs and wages.

This paper examines how visa and immigration policies are related to the salaries of American and foreign IT professionals employed in the United States. The most common complaint about foreign professionals is that they work for lower wages and that employers hire them to substitute for higherwage U.S. professionals. A second-order impact of such immigration policies is that low-wage foreign professionals then depress the demand for and the wages of U.S. professionals. Using a sample of more than 50,000 foreign and American IT professionals in the United States, we study relative wages of foreign and U.S. citizen IT professionals. Although anecdotal evidence describes examples where foreign professionals are paid low wages, the findings in this paper question whether these stories are representative of the population of IT professionals in the United States. An exogenous change (driven more by political than economic considerations) in the supply of foreign IT professionals during 2001-2003 from a congressionally mandated increase in visa caps for $\mathrm{H}-1 \mathrm{~B}$ professionals provides a natural experiment to study how annual visa caps affect salary premiums (i.e., higher wages of foreign IT professionals compared to U.S. citizen IT professionals) for foreign IT professionals. Our work also complements prior research on the compensation of IT professionals (e.g., Ang et al. 2002; Levina and Xin 2007; Mithas and Krishnan 2008, 2009; Slaughter et al. 2007, Truman and Baroudi 1994) by examining how compensation and returns on human capital vary across IT professionals based on their citizenship or visa status.

\section{Background and Hypotheses}

\subsection{Foreign IT Professionals in the United States}

Foreign-born people (i.e., people who reside in a country other than the country of their birth) constitute less than $3 \%$ of the population of the world, or approximately 175 million people in 2004 (Bhagwati 2004). However, they are not distributed equally across all countries. Developed countries have about two-thirds of all the immigrants, where the foreign born constitute about $9 \%$ of the population, whereas developing countries have the remaining immigrants, where they constitute about $1.5 \%$ of the population (Freeman 2006). This study focuses on foreign-born people in the United States and, more specifically, on those who are non-U.S. citizen IT professionals. There are fewer non-U.S. citizen IT professionals than foreign-born IT professionals because a large fraction of foreign-born IT professionals who initially enter the United States on a temporary work visa eventually become U.S. citizens.

Foreign-born IT professionals enter into the United States' labor market using two principal routes: permanent immigration and nonimmigrant or temporary work visa. Permanent immigration can be employer sponsored or family sponsored. For example, EB is an employment-based program for permanent immigration with an annual cap of 140,000 , and in most cases it requires an employer to show that immigrant admissions will not affect American workers adversely. Typically, IT professionals immigrate to the United States using this route after working for a few years under some temporary work visa programs such as H-1B or L1.

Among temporary work visa categories, H-1B, L1, and TN are the ones most frequently used to bring IT professionals in the United States (for a brief review of other visa categories, see USCIS 2007). H-1B is a temporary work visa issued to employers to hire professionals in specialty occupations that require at least a bachelor's degree and the theoretical and practical application of highly specialized knowledge and skills. L1 is an intracompany transfer visa issued to employers to transfer specialized knowledge workers, managers, or executives to the United States for 
temporary assignments for five to seven years without any annual cap or prevailing wage requirement (Canadian nationals as intracompany transferees do not need an L1 visa). L1 visa usage has always been less than the H-1B visa usage. A TN visa allows Canadian and Mexican professionals to temporarily work in the United States in qualifying occupations under the North American Free Trade Agreement. A TN visa is issued for up to one year at a time but can be renewed an unlimited number of times.

Of these temporary work visas, it is the use of $\mathrm{H}-1 \mathrm{~B}$ visas that has been a source of major controversy, partly because visas in the $\mathrm{H}-1 \mathrm{~B}$ category exceed those in other visa categories in specialty occupations (Herbst 2008, Hira 2004, Matloff 2004). The Immigration Act of 1990 established the H-1B visa category, replacing the old $\mathrm{H}-1$ category, to allow foreign nationals to work in the United States for a sponsoring employer for up to six years. Although $\mathrm{H}-1 \mathrm{~B}$ is a non immigrant visa, the law allows for dual intent and permits a worker to apply for legal permanent resident (also called "green card") status while holding the $\mathrm{H}-1 \mathrm{~B}$ visa. The maximum number of new $\mathrm{H}-1 \mathrm{~B}$ visas issued per year had an annual cap of 65,000 from fiscal years 1991 to 1998, 115,000 in 1999 and 2000, 195,000 from 2001 to 2003, and 65,000 thereafter. Beginning with the 2005 fiscal year, Congress allowed 20,000 additional visas for foreigners graduating from U.S. universities with a master's or a higher degree (Constable 2007, McGee 2006).

According to a study, about $60 \%$ of $\mathrm{H}-1 \mathrm{~B}$ visas are issued to the IT industry (Park 2007). Because $\mathrm{H}-1 \mathrm{~B}$ visa applications have exceeded the annual caps for new H-1B visas in recent years, the U.S. Citizenship and Immigration Services (USCIS) allocated visas using a first-come-first-served or a lottery process, denying some $\mathrm{H}-1 \mathrm{~B}$ petitions from companies such as Microsoft. Although the total number of new $\mathrm{H}-1 \mathrm{~B}$ professionals in the U.S. economy is less than $0.1 \%$ of the U.S. labor force, they constitute an important source of the global workforce for hightechnology companies such as Microsoft, Intel, and Google (NFAP 2007). Figure 1 shows the annual cap and actual visas issued from 1998 to 2006 (Constable 2007, McGee 2006).

\subsection{Prior Literature}

Although many firms recognize the benefits of work visas and employ foreign professionals, use of such work visas raises questions about the likely impact of high-skill immigration on the economy and U.S. citizens. On one hand, some studies argue that use of foreign professionals in the U.S. economy has many benefits for firms, other professionals, and the regional or national economy (Friedberg 2007). For example, Saxenian (2002) notes that every 1\% increase
Figure 1 Trends in H-1B Visa Caps and Actual Visas Issued by Fiscal Years

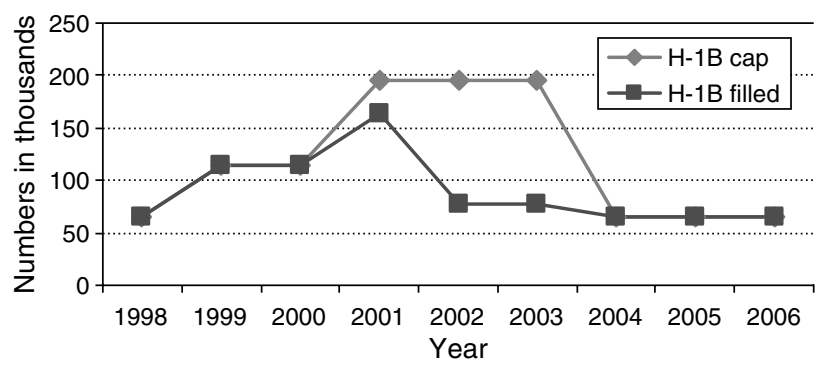

Notes. Fiscal years (FYs) start on October 1 and end on September 30. As an example, fiscal year 1998 starts on October 1, 1997, and ends on September 30, 1998. In fiscal years 2005 and 2006, 20,000 additional visas were available for foreign students graduating from U.S. universities (Constable 2007, McGee 2006). Nonprofits such as universities and research institutions are exempt from visa caps since FY 2001. H-1B applications exceeded the annual quota of 65,000 on the first day of applications, that is, April 1, 2007 , for FY 2008. USCIS received about 124,000 applications against a total cap of 85,000 in the first two days of applications for FY 2008. The cap for FY 2007 was exhausted on May 31, 2006, and the cap for FY 2006 exhausted in August 2005. For FY 2008, USCIS allocated visas using a lottery. The lottery system was not used in FY 2007.

in the number of first-generation immigrants from a given country is associated with a $0.5 \%$ increase in exports to that country from California, a hotbed of high technology and innovation in America. She argues that high-skill immigrants make "everyone better off" by creating new jobs in the United States and new ties with emerging economies, leading to enhanced trade and investment flows. These trade and investment flows have become even more important with the rising share of international profits at U.S. companies, which rose from $5 \%$ in 1960 s to about a quarter of all profits in 2007; there is significantly higher revenue growth potential in emerging markets than in developed markets (Aeppel 2007, Agtmael 2007, Gupta and Wang 2009). Recent studies show that international graduates and skilled immigrants make significant contributions to U.S. innovative activity in terms of total patents and patents issued to U.S. universities and other entities (Chellaraj et al. 2005, Hunt and Gauthier-Loiselle 2009, Kerr and Lincoln 2010). Several other studies show that restrictive visa policies can reduce job creation and innovation opportunities in the United States (NFAP 2007, 2008).

At the same time, similar to concerns about potentially adverse impacts of offshoring on jobs and wages (Mithas and Whitaker 2007), high-skill immigration also raises issues related to job and wage prospects of foreign and American professionals. Some worry that firms may be exploiting $\mathrm{H}-1 \mathrm{~B}$ workers as a source of cheap labor. For example, one of the executives of an Indian outsourcing firm observed that the annual cost to the company of an Indian worker employed in the United States is lower than the cost to hire 
an American worker (Singh 2003). Others argue that misuse of visa provisions such as the ones contained in the $\mathrm{H}-1 \mathrm{~B}$ program may adversely affect the wages of American professionals. In turn, lower wages may reduce future student enrollments in information systems programs, leading to further offshoring due to a shortage of IT professionals in the United States, thus creating a vicious cycle (Hirschheim et al. 2007).

Despite the importance of high-skill immigration policy for the competitiveness of U.S. firms and the U.S. economy, with some exceptions (e.g., Borjas 2005, Friedberg 2007, Orrenius and Zavodny 2007, Zavodny 2003), very few academic studies have examined the impact of high-skill immigration on compensation of American and foreign workers in the United States, and none have reported on IT professionals. Much of the labor economics literature on immigration has studied low-skill immigration, reporting negligible or low adverse impact of low-skill immigration on natives' outcomes (e.g., Borjas and Tienda 1987, Card 1990, Friedberg and Hunt 1995). Matloff (2003) reviews some studies (mostly conducted by think tanks and research organizations) that do grapple with the impact of $\mathrm{H}-1 \mathrm{~B}$ and related visa policies with reference to knowledge workers and IT professionals, and concludes that firms pay $\mathrm{H}-1 \mathrm{Bs}$, on average, $15 \%-33 \%$ less than "comparable" U.S. IT professionals (Matloff 2004). However, such a conclusion needs to be viewed with caution because many of these studies, with one or two exceptions, use data prior to 2000 and do not show the "comparability" of H-1B and U.S. professionals on attributes such as education, IT experience, and firm size. Furthermore, they also do not report statistical significance and do not use the types of econometric models with appropriate functional form or control variables that are common in compensation studies (see Ang et al. 2002; Mithas and Krishnan 2008, 2009; Orrenius and Zavodny 2007).

Some other studies use Labor Condition Applications (LCA) data on "wage rate" and "prevailing wages" from the Department of Labor to claim that average $\mathrm{H}-1 \mathrm{~B}$ salaries are lower than the mean annual salaries for these jobs as determined by the U.S. Bureau of Labor Statistics' Occupational Employment Statistics survey of employers (Miano 2005). These LCA-based studies also do not control for education and experience of IT professionals, and many consider them unreliable because they do not use actual salary data, and many approved LCAs may not result in actual H-1B visas (Roman 2006). In addition, many of the assumptions underlying the debates on the likely impact of work visas on compensation, such as a shortage of American IT labor or the American labor with Ph.D.'s (Matloff 2003) and whether foreign labor is more exploitable or works longer hours (Matloff 2003), have remained unexamined.

Among studies of high-skill immigration in the labor economics literature, Borjas (2005), using data from surveys of earned doctorates and doctoral recipients from 1968 to 2000 in 22 science and engineering fields, reports that an immigration-induced $10 \%$ increase in the supply of doctorates reduces the earnings of that cohort of doctoral recipients by 3\%. As Borjas (2005) himself notes, this finding needs to be viewed with caution because the earnings of a cohort of doctoral recipients could also decline if native workers had entered the doctoral programs because foreign students were denied entry into the United States. An additional reason for caution is that one other study of high-skill immigration in the Israeli labor market suggests no adverse impact of immigration on native outcomes in terms of wage or employment growth (Friedberg 2001). More recently, Friedberg's (2007) study of the regional economic impact of knowledge workers from India and China in New Jersey, New York, and Pennsylvania concluded that these workers are "good" for firms and the overall regional economy. Other studies (Orrenius and Zavodny 2007, Zavodny 2003) also do not find any adverse effects of larger immigrant inflows on natives' wages in the high-skill professional and service occupations.

In summary, none of the previous studies examined the relative wages of foreign and American IT professionals specifically and how exogenous changes in visa policies impact the wage differences among foreign and American IT professionals.

\subsection{Hypotheses}

2.3.1. Relative Wages of American and Foreign IT Professionals: Are American and Foreign IT Professionals Substitutes or Complements? Economic theory suggests that the wages of American and foreign IT professionals will be determined by the aggregate supply and demand of IT professionals and whether foreign and American professionals substitute or complement each other (for reviews of this literature, see Borjas 1989, 1994; Friedberg and Hunt 1995; Orrenius and Zavodny 2007). Consider the impact of aggregate demand and supply of IT professionals first. Although aggregate demand and supply factors will affect wages of foreign and American IT professionals, they alone do not tell us whether foreign IT professionals will earn more or less than American IT professionals, unless we also know how foreign and American IT professionals substitute or complement each other.

Foreign and U.S. workers are substitutes if employers are indifferent and are willing to hire either 
worker for a given position. Workers are complements if hiring a person from one group increases the demand for a worker in the other group. What is the likely impact of substitution or complementarity in the case of IT workers? If firms treat foreign and American IT professionals as substitutes for each other, then an exogenous increase in overall supply of IT professionals will depress the wages of all IT professionals regardless of their citizenship and visa status. Likewise, if firms treat foreign and American IT professionals as substitutes for each other, an exogenous increase in demand for IT professionals (as happened during the dot-com boom and when firms were preparing to meet the $\mathrm{Y} 2 \mathrm{~K}$ requirements) will increase the wages of all IT professionals regardless of their citizenship and visa status. Although it is hard to predict how wages of foreign and American IT professionals will change differentially if firms treat foreign and American IT professionals as substitutes, this is not the case if firms treat them as complements. Under a complementarity argument, an exogenous decrease in supply of foreign IT professionals will raise salary premiums for foreign IT professionals. This is because the decrease in the supply of foreign IT professionals can decrease the demand for American IT professionals with whom foreign IT professionals are complements and increase the wages of remaining foreign IT professionals because of higher demand for their skills and competencies.

We draw on human capital and the expertise-based arguments (Boh et al. 2007) to understand whether American and foreign IT professionals are substitutes or complements. We posit that U.S. companies pay a premium for non-U.S. or migrant IT professionals for at least three reasons. Consider first some of the differences in human capital of foreign and American IT professionals that may make foreign IT professionals complements of American IT professionals. Beginning with Schultz (1961), migration to seek better job opportunities has been considered an important component of human investment and human capital (along with education, training, study programs, and health) (also see Becker 1993). Migration serves as a proxy for willingness to take risks and meet the challenges associated with the disruption caused by a move to a different location and cultural, and economic environment. Those who emigrate are likely to have high motivation and an ability to quickly learn and adapt to new situations. Some of these factors are not fully captured in education and experience, which are conventionally used to account for differences in human capital endowments. Therefore, one of the reasons that foreign professionals can have a salary premium is the intangible human capital (e.g., knowledge of markets and cultures outside the United States, social relationships with the colleagues at firms located in home countries; knowledge of and access to networks of knowledge creation in home countries; ability to spot, circulate, and mix ideas and skills from different parts of the world) associated with an immigrant population that has undergone rigorous screening and selection processes by the sponsoring firms and visa-granting authorities (Oettl and Agrawal 2008, The Economist 2009).

The positive selection effect is even more likely to apply to IT professionals because they fall under high-skill immigration as opposed to workers in other professions who are low-skill immigrants (Borjas 1987). Because of significant competition among eligible IT professionals trying to migrate to developed economies such as the United States, screening is particularly rigorous for foreign IT workers, and firms are likely to be able to tap the brightest talent from abroad. Firms are likely to price some of the dimensions of intangible human capital of the foreign workers (which are correlated with their non-U.S. citizenship or visa status) in the form of higher salaries, even though such IT professionals may have same level of education as their American counterparts.

Second, foreign professionals are often willing to travel and work for extended periods across country borders, providing greater flexibility to firms based in the United States who want to expand their overseas operations or coordinate operations in different parts of the world. Foreign IT professionals working for U.S. firms frequently act as boundary spanners to bridge the cultural issues arising in interactions with the staff of the foreign outsourcing providers or customers located outside the United States. This boundary spanning work requires these IT professionals often to travel abroad and work at night or in early morning hours to coordinate with IT professionals, vendors, or business partners in other time zones around the world (Krishna et al. 2004, Levina and Kane 2009). The relative willingness of foreign IT professionals working for U.S. firms to travel abroad and to work unusual hours to coordinate with colleagues in different time zones can lead to their higher valuation. On the other hand, American professionals often demand high salary premiums for postings abroad, which are considered to cause hardships (Ipsen 1994). There is also some evidence that foreign professionals provide greater flexibility to employers in terms of mobility (i.e., traveling and redeployment) even within the United States, compared to American IT professionals (Hari 2009).

Finally, another factor that is relevant for considering the substitution and complementarity of foreign and American IT professionals comes from the recent work that uses the knowledge-based view and 
expertise-based arguments in studying dispersed collaboration (Boh et al. 2007). On one hand, because U.S. firms need IT professionals to expand their business and tailor their goods and services for global markets, they can not satisfy all their needs by restricting themselves to only U.S. citizen IT professionals. This is partly because of the presumed shortage of such highly skilled IT professionals in the United States as we noted earlier (see Agarwal and Ferratt 1999, Lewin et al. 2009, U.S. Department of Commerce 1997). Even if firms can find sufficient technically qualified U.S. citizen IT professionals, technical skills alone may not be sufficient to meet the needs of firms. This is because global responsiveness may require firms to hire IT professionals familiar with foreign culture, language, and business practices to more easily help to coordinate with foreign vendors and customers. On the other hand, hiring foreign IT professionals creates extra costs associated with screening, selection, and visa processes. Following the reasoning in Boh et al. (2007), we posit that organizations are aware of the costs, benefits, and potential uncertainties related to the recruitment of foreign IT professionals. Considering these factors, firms recruit foreign IT professionals for the skills and expertise that they can not acquire by restricting themselves to American IT professionals. Because of the rigor demanded by the visa and immigration processes, firms' own need to hire a technically and culturally competent workforce, and the significant desire and competition among foreign workers to gain experience in the U.S. labor market, firms are able to attract the highest-quality foreign talent. The significant expertise (considering technical, behavioral, and cultural proficiency) that the foreign IT professionals have would therefore explain why foreign workers command a salary premium over American IT professionals.

Based on the foregoing discussion and relying on the human capital- and expertise-based arguments, we posit that foreign IT professionals, because of their intangible human capital, rigorous screening and selection processes, and willingness to work across borders, are likely to earn higher wages than U.S. citizen IT professionals. Thus,

Hypothesis 1A (H1A). Compared to U.S. citizens, non-U.S. citizen IT professionals receive a salary premium after controlling for their educational qualifications and work experience.

Whereas non-U.S. citizen IT professionals are likely to receive higher wages compared to U.S. citizens because of their intangible human capital as discussed above, some non-U.S. citizens are likely to do better compared to others. Among non-U.S. citizen IT professionals, we make a distinction between those who are on a work visa and those who are green card holders. Using arguments similar to the ones for H1A, we posit that because of intangible human capital, work ethic and willingness to work across borders, and rigorous selection processes, firms are likely to value foreign IT professionals with a work visa more than U.S. citizens. Thus,

Hypothesis 1B (H1B). Compared to U.S. citizens, foreign IT professionals with a work visa receive a salary premium after controlling for their educational qualifications and work experience.

Next, we posit that green card holders will have a salary premium compared to U.S. citizens and those with an H-1B or some other work visa. This prediction stems from the fact that green card holders are by definition non-U.S. citizens (they were in a different status earlier, most likely a work visa in the case of IT professionals). As we argued above, firms are likely to value their intangible human capital more than they value intangible human capital of U.S. citizen IT professionals. Possession of a green card provides greater bargaining power and job security for an IT professional compared to someone with a work visa because (1) employers typically hold work visas, which makes it difficult for an IT professional to easily change his or her employer and (2) work visas are of a limited duration. In addition, green card holders are also likely to possess valuable skills because the sponsoring employer needs to make such a case as part of the application process; the government also verifies such claims through its screening processes. Finally, because obtaining permanent residency status requires some time, green card holders have a longer time period and opportunity to assimilate to American culture and business practices than work visa holders who have had relatively limited experience in the United States. Thus,

Hypothesis 1C (H1C). Compared to U.S. citizens and work visa holders, IT professionals with a green card command a salary premium after controlling for their educational qualifications and work experience.

2.3.2. How H-1B Visa Caps Affect Compensation of American and Foreign IT Professionals. Hypotheses $1 \mathrm{~A}-1 \mathrm{C}$ suggest complementarity among American and foreign IT professionals implied in the human capital-based discussion, which argues that foreign IT professionals possess some unique skills and competencies that are not fully reflected in observable indicators of human capital such as education and experience. We can make a more direct assessment of substitution versus complementarity by considering shifts in relative wages of American and foreign IT professionals in response to an exogenous increase in the supply of foreign IT professionals. Annual visa 
caps mandated by Congress determine the supply of new foreign IT professionals, and the total supply of IT professionals in the U.S. economy. Any increase (decrease) in aggregate supply of IT professionals is likely to decrease (increase) the average wages of all IT professionals regardless of whether they are American or foreign born. The variation in salary premiums of foreign professionals in response to visa caps can help infer whether American and foreign IT professionals are substitutes or complements in other words, whether high-skill immigration makes everyone (i.e., American and foreign IT professionals) better off or is a zero-sum game.

If visa caps restrict the inflow of foreign IT professionals in the lower segment of the market, and if foreign professionals are indeed complementary to American IT professionals, then a scarcity of foreign IT professionals from lower visa cap regimes will be reflected in higher salary premiums. In addition, following expertise-based reasoning in Boh et al. (2007), when the $\mathrm{H}-1 \mathrm{~B}$ visa cap is fully utilized, organizations will be restricted in terms of their ability to recruit foreign IT professionals. Hence, firms will compete with each other to select the foreign IT professionals with the skills that they require leading to a higher salary premium for these foreign IT professionals when the $\mathrm{H}-1 \mathrm{~B}$ visa cap is fully utilized. We expect the premium to drop in "soft" labor markets when supply of foreign professionals exceeds demand, which can happen when visa caps are high and/or the demand for foreign IT professionals is low due to a slump in production of IT services. A further implication of an exogenous increase in supply of foreign IT professionals for understanding the substitution and complementarity argument is that a decrease in supply of foreign IT professionals will affect some foreign IT professionals more than others. For example, a reduction in the supply of foreign IT professionals on work visas will have greater effect on wages of these foreign IT professionals and less effect on wages of foreign IT professionals with a green card who are not subject to caps. Thus,

HүротнеSIS 2 (H2). The salary premium for foreign IT professionals on work visas is more strongly affected when the $H-1 B$ visa cap is fully utilized than when the visa cap is underutilized.

Following prior work on compensation of IT professionals (e.g., Ang et al. 2002; Levina and Xin 2007; Mithas and Krishnan 2008, 2009; Truman and Baroudi 1994) and subject to data availability, we identify and control for other relevant variables in our models of compensation for IT professionals, such as gender, institutional factors (the type of firm or industry that an IT professional belongs to such as IT versus nonIT industry, dot-com versus non-dot-com firms, for-profit versus nonprofit firms, firm size), and the average number of hours per week worked by the respondent. We also use dummies for each year of the salary survey, which enables us to control for an unemployment situation and, thus, consideration of demand factors in the labor market.

\section{Research Design and Methodology}

The United States is the largest labor market for IT professionals, employing close to 3.5 million in an economy that employs about 140 million workers annually. According to an estimate, there are about 700,000 temporary high-skill foreign professionals in the United States on work visas (approximately 500,000 in the H-1B category alone), and about $60 \%$ of these are in the IT profession (Lowell 2007).

Figures 2 and 3, based on Bureau of Labor Statistics data, show trends in employment and mean wages of IT professionals in the United States. Figure 2 shows that the demand for IT professionals peaked around 2000 at the height of the dot-com boom and Y2K concerns. Then employment trended down until 2003 with a general downtrend in the economy in the aftermath of dot-com debacle, the September 2001 attacks, and declining $\mathrm{Y} 2 \mathrm{~K}$ and enterprise resource planning implementation projects. Employment picked up beginning in 2004, rising gradually to become higher in 2006 than it was in 2000. Figure 3 shows that nominal mean wages have been increasing in IT occupations, but adjusted wages are generally flat with a seesaw pattern and a weak downward trend since 2004 .

Together, based on the aggregate data and trends in Figures 2 and 3, it is difficult to attribute flat mean IT wages, despite rising overall demand for IT professionals, to an influx of foreign IT professionals. The mean IT wage includes compensation of both American and foreign IT professionals (known as the "composition" problem in the immigration economics literature; see Friedberg and Hunt 1995), and it is also influenced by other macroeconomic factors and

\section{Figure 2 Overall IT Employment from the Bureau of Labor Statistics}

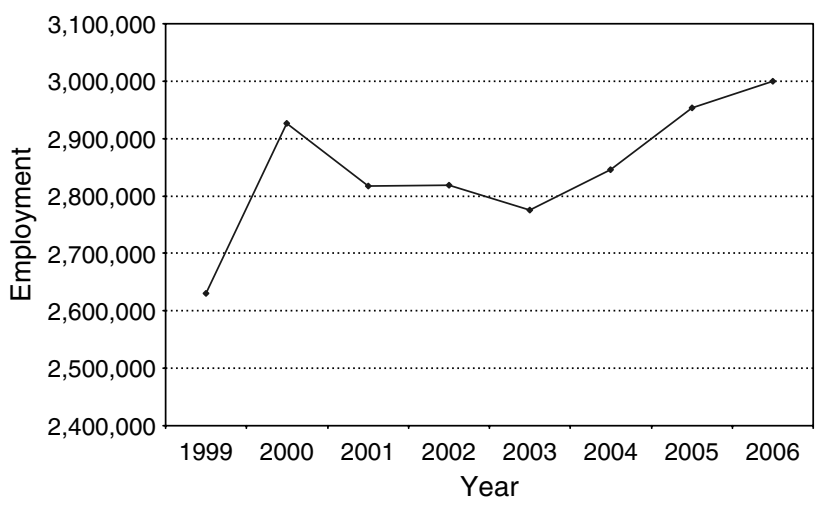


Figure 3 Mean IT Wage in the United States from the Bureau of Labor Statistics

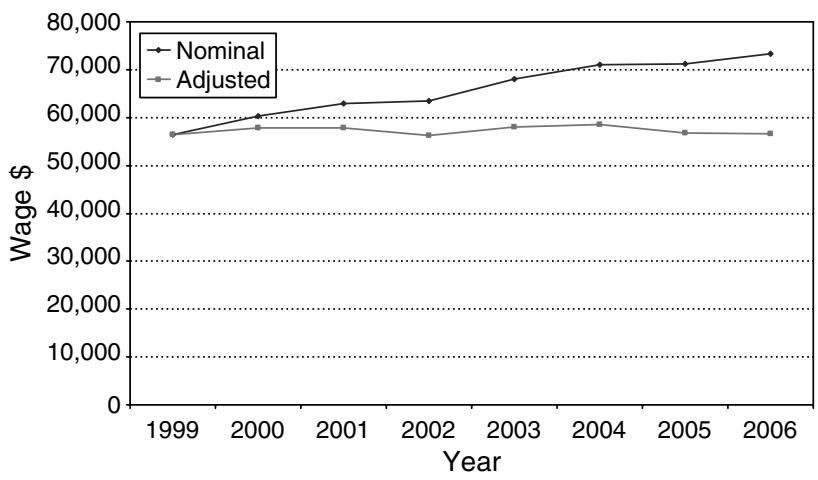

Notes. For wages in this figure, the statistics from the Bureau of Labor Statistics include the average wage and number of workers in 10 categories of IT jobs (computer and information systems managers; computer and information scientists, research; computer programmers; computer software engineers, applications; computer software engineers, systems software; computer support specialists; computer systems analysts; data base administrators; network and computer systems administrators; network systems and data communications analysts). The annual wage data in the graph is a weighted average of the averages in each category based on the number of workers in that category.

the offshoring phenomenon, which can put downward pressure on the compensation of IT professionals (Apte and Mason 1995, Rodrik 1997). Aggregate data also makes it difficult to know whether firms value American and foreign IT professionals as substitutes or complements. We employ microdata on compensation of American and foreign IT professionals to answer this question.

\subsection{Data}

The data used in this study come from national Web surveys for the 2000-2005 period conducted by InformationWeek, a leading and widely circulated IT publication in the United States. The salary surveys were designed by InformationWeek in consultation with Hewitt Associates, a global management consulting firm with an extensive practice in compensation consulting. To our knowledge, this is the largest and most complete source for salaries of IT professionals in the United States. InformationWeek is a reliable source of information, and previous academic studies have used data from its surveys (Bharadwaj et al. 1999, Mithas and Krishnan 2008, Mithas and Whitaker 2009, Rai et al. 1997, Santhanam and Hartono 2003).

The overall sample and sample of non-U.S. citizen foreign-born IT professionals in our study appear reasonably representative of the U.S. population (see Mithas and Krishnan 2008 for additional details on the data). Table A1 in the online appendix (provided in the e-companion) ${ }^{2}$ provides details on

\footnotetext{
${ }^{2}$ An electronic companion to this paper is available as part of the online version that can be found at http://mansci.journal.informs.org/.
}

representativeness of the InformationWeek data by comparing it with a profile of IT professionals in other studies. As noted earlier, this study focuses on a subset of the foreign-born IT professionals in the United States who are non-U.S. citizens. The number and fraction of non-U.S. citizen IT professionals is less than that of all foreign-born people because a large fraction of foreign-born IT professionals eventually become naturalized U.S. citizens. According to some estimates (Lowell 2001, National Research Council 2001), the IT profession in the United States has close to $20 \%$ foreign-born workers, which include both U.S. citizens and non-U.S. citizens. Non-U.S. citizen IT professionals in our study constitute $4.73 \%$ of the total sample, or approximately $25 \%$ of the $20 \%$ all foreignborn IT professionals. Although no reliable data is available on the percentage of IT professionals with green cards or on work visas eventually becoming citizens, assuming that $75 \%$ of foreign-born IT professional eventually become U.S. citizens, as estimated for other workers (see Friedberg and Hunt 1995, Gurcak et al. 2001), leaves $25 \%$ who are not citizens. This $25 \%$ times the $20 \%$ of foreign-born IT professionals in our sample gives an estimate of $5 \%$ of non-U.S. citizens, which compares to $4.73 \%$ in our data.

Yet another way to assess the representativeness of foreign-born non-U.S. citizens in our sample is to compare the fraction of IT professionals with a green card or work visa by years of IT experience. Gurcak et al. (2001) report that of the foreign-born students with doctorates earned in 1984 and those in 1987 in the United States on a green card, 85\% remained in the United States by 1992. Likewise, of the foreignborn students with doctorates earned in 1984 and those in 1987 in the United States on a work visa, 55\% remained in the United States by 1992 (eight years after graduation). Typically, it is easier to get an $\mathrm{H}-1 \mathrm{~B}$ visa or a green card if one has a doctorate, hence we would expect a smaller percentage of IT professionals as temporary residents or green card holders than reported by Gurcak et al. (2001) after 10 years of IT experience in the United States. This expectation is confirmed in our data: $54 \%$ of non-U.S. citizens with less than 10 years of IT experience in our sample are green card holders (as a percentage of all green card holders in our sample), and $65 \%$ are on an $\mathrm{H}-1 \mathrm{~B}$ or some other work visa (as a percentage of all IT professionals on an $\mathrm{H}-1 \mathrm{~B}$ or some other work visa in our sample). These figures, which appear in consonance with prior studies, provide further confidence in representativeness of foreign-born non-U.S. citizens in our sample.

We compared the distribution of U.S. citizen IT professionals and non-U.S. citizens across job titles in our data and found them to be similar. We also 
Table 1

Variable Definition

\begin{tabular}{|c|c|}
\hline Variable & Definition/Operationalization \\
\hline Cashcomp & $\begin{array}{l}\text { Cash compensation of IT professionals by adding their base pay and bonus; we converted the nominal dollar value of compensation in } \\
\text { each year to } 1999 \text { dollars by deflating salary figures for 2000-2005 using the Employment Cost Index for all workers computed by } \\
\text { the Bureau of Labor Statistics }\end{array}$ \\
\hline Uscit & Whether the respondent is a citizen of the United States $(1=$ yes, $0=$ no); this variable is available for $2000-2005$ \\
\hline$H-1 B$ & $\begin{array}{l}\text { Whether the respondent is working in the United States on an } \mathrm{H}-1 \mathrm{~B} \text { visa or other work visa such as EB, } 0, \mathrm{TN}, \mathrm{L} 1(1=\mathrm{yes}, 0=\text { no); } \\
\text { this variable is available only from } 2000-2003\end{array}$ \\
\hline Green card & $\begin{array}{l}\text { Whether the respondent is working in the United States on a green card (also known as permanent residency, } 1=\text { yes, } 0=\text { no); this } \\
\text { variable is available from 2000-2003 }\end{array}$ \\
\hline Edubach & Whether the highest educational degree of the respondent is a bachelor's degree $(1=$ yes, $0=$ no) \\
\hline Edumaster & Whether the highest educational degree of the respondent is a master's degree other than an MBA, $(1=$ yes, $0=$ no $)$ \\
\hline Edusomecoll & Whether the highest educational degree of the respondent is some college education $(1=$ yes, $0=$ no) \\
\hline Eduphd & Whether the highest educational degree of the respondent is a Ph.D. $(1=$ yes, $0=$ no) \\
\hline Edumba & Managerial competency of a respondent is measured by whether he or she has an MBA $(1=$ yes, $0=$ no) \\
\hline Itexpcurrco & Firm-specific IT experience or IT experience (in years) at the current firm \\
\hline Itexpothercos & General IT experience or IT experience (in years) at previous firms \\
\hline Totexp & Total work experience; following previous studies in labor economics, we operationalized this as age-6-years of education \\
\hline Itind & $\begin{array}{l}\text { Indicates the type of industry to which a respondent belongs ( } 1=\text { IT vendors and service providers including telecommunications, and } \\
0 \text { otherwise) }\end{array}$ \\
\hline Hiit & $\begin{array}{l}\text { Indicates the type of industry to which a respondent belongs ( } 1 \text { = IT-intensive industries, and } 0 \text { otherwise). Following Mittal and } \\
\text { Nault's (2009) conceptualization of "level of use of IT" to discriminate IT-intensive from the non-IT-intensive industries, we classified } \\
\text { industries as IT intensive using the average IT spending as a ratio of sales across industries, as reported in InformationWeek } 500 \\
\text { annual surveys. We classified biotech, business consulting and related services, finance, health care, IT, telecommunications, and } \\
\text { media as IT-intensive because the average IT spending in these industries was higher than the average IT spending across all } \\
\text { industries. }\end{array}$ \\
\hline Dot-com & Indicates type of firm ( $1=$ the respondent works with a dot-com type of firm, and 0 otherwise) \\
\hline Male & Indicates the gender of the respondent (male $=1$, and female $=0$ ) \\
\hline Empno & $\begin{array}{l}\text { Denotes organization size and is a bracketed variable that indicates a range for the number of employees in the respondent's firm } \\
(1=\text { up to } 100 ; 2=101-1,000 ; 3=1001-10,000 ; \text { and } 4=\text { more than } 10,000) \text {. }\end{array}$ \\
\hline Npg & Indicates a respondent's industry sector ( 1 = nonprofits and government organizations, and 0 otherwise) \\
\hline Hrsperwk & The average number of hours per week put in by the respondent \\
\hline Capreached & Indicates that the $\mathrm{H}-1 \mathrm{~B}$ visa cap is fully utilized in that year (cap = 1 when visa cap is fully utilized, else 0 ) \\
\hline
\end{tabular}

compared the distribution of U.S. citizen IT professionals and non-U.S. citizens across U.S. states in our data and found them to be similar. Results of nonparametric Kolgomorov-Smirnov tests also suggest that the distribution of American and foreign respondents does not differ across job titles or U.S. states. ${ }^{3}$ These results suggest that foreign IT professionals are not self-selecting high-paying jobs or regions of the country.

The salary surveys covered more than 50,000 IT professionals for which all the data relevant for this study is available. The salary surveys contain information on respondents' cash compensation,

\footnotetext{
${ }^{3}$ Despite the strengths of the data set, it is likely that the survey is more representative of the types of IT professionals who read trade magazines such as InformationWeek. Because InformationWeek subscription and readership is unrelated to citizenship (the subscription application does not ask citizenship status or place of birth, it asks only month of birth), and assuming that the survey responses are not correlated with citizenship or visa status of the respondent, then use of this data to answer our research question does not create any potential bias.
}

demographics, human capital-related variables, and institutional variables. We used similar and comparable questions across the years to construct the variables used in this study. ${ }^{4}$ We converted the nominal dollar value of compensation each year to 1999 dollars using the Employment Cost Index for all workers computed by the Bureau of Labor Statistics.

Table 1 provides a description of variables in this study. The InformationWeek surveys have a specific question (Are you a citizen of the United States?) for years 2000-2005 to identify the citizenship status of each respondent. InformationWeek surveys have another specific question (Are you working in the United States on an H-1B visa or other work visa?) for years 2000-2003 to identify the visa status of each respondent who is a non-U.S. citizen. Both of these

\footnotetext{
${ }^{4}$ We did not find any common respondents in these surveys across years when we tried to match on the e-mail addresses that were available for a subset of respondents across years. We report yearby-year empirical results to avoid potential concerns due to any overlap of respondents across years.
} 
Table 2 Descriptive Statistics of IT Professionals by Citizenship and Visa Status (2000-2005)

\begin{tabular}{|c|c|c|c|c|c|c|c|c|c|c|}
\hline & \multicolumn{2}{|c|}{$\begin{array}{c}\text { Total } \\
(N=51,363)\end{array}$} & \multicolumn{2}{|c|}{$\begin{array}{c}\text { Non-U.S. citizens } \\
(N=2,428)\end{array}$} & \multicolumn{2}{|c|}{$\begin{array}{c}\text { U.S. citizens } \\
(48,935)\end{array}$} & \multicolumn{2}{|c|}{$\begin{array}{l}\mathrm{H}-1 \mathrm{~B} \text { or other } \\
\text { work visa holders } \\
\quad(N=809)\end{array}$} & \multicolumn{2}{|c|}{$\begin{array}{l}\text { Green card holders } \\
\qquad(N=850)\end{array}$} \\
\hline & Mean & SD & Mean & SD & Mean & SD & Mean & SD & Mean & SD \\
\hline Lncashcomp & 11.12 & 0.44 & 11.23 & 0.44 & 11.11 & 0.44 & 11.23 & 0.41 & 11.27 & 0.45 \\
\hline Eduphd & 0.02 & 0.13 & 0.04 & 0.19 & 0.02 & 0.13 & 0.03 & 0.16 & 0.05 & 0.21 \\
\hline Edumba & 0.07 & 0.26 & 0.08 & 0.27 & 0.07 & 0.26 & 0.08 & 0.27 & 0.07 & 0.26 \\
\hline Edumaster & 0.15 & 0.35 & 0.3 & 0.46 & 0.14 & 0.35 & 0.3 & 0.46 & 0.28 & 0.45 \\
\hline Edubach & 0.45 & 0.50 & 0.43 & 0.49 & 0.45 & 0.5 & 0.5 & 0.5 & 0.39 & 0.49 \\
\hline Edusomecoll & 0.15 & 0.35 & 0.06 & 0.24 & 0.15 & 0.36 & 0.04 & 0.19 & 0.1 & 0.29 \\
\hline Itexpcurrco & 6.41 & 6.01 & 4.35 & 3.95 & 6.51 & 6.08 & 3.38 & 2.88 & 4.58 & 4.24 \\
\hline Itexpothercos & 7.36 & 7.70 & 6.76 & 6.31 & 7.39 & 7.76 & 6.33 & 6.23 & 7.04 & 6.47 \\
\hline Totexp & 19.29 & 9.12 & 13.43 & 7.56 & 19.58 & 9.09 & 11.23 & 6.98 & 14.75 & 7.58 \\
\hline Itind & 0.19 & 0.40 & 0.35 & 0.48 & 0.19 & 0.39 & 0.46 & 0.5 & 0.29 & 0.45 \\
\hline Dot-com & 0.05 & 0.21 & 0.08 & 0.27 & 0.05 & 0.21 & 0.1 & 0.3 & 0.08 & 0.27 \\
\hline Hiit & 0.48 & 0.50 & 0.63 & 0.48 & 0.48 & 0.5 & 0.72 & 0.45 & 0.58 & 0.49 \\
\hline Empno & 2.68 & 1.07 & 2.65 & 1.13 & 2.68 & 1.07 & 2.59 & 1.15 & 2.65 & 1.09 \\
\hline$N p g$ & 0.12 & 0.33 & 0.05 & 0.22 & 0.12 & 0.33 & 0.03 & 0.17 & 0.06 & 0.23 \\
\hline Hrsperwk & 48.03 & 7.40 & 47.86 & 7.64 & 48.04 & 7.39 & 48.36 & 7.84 & 48.01 & 7.59 \\
\hline Male & 0.85 & 0.36 & 0.89 & 0.32 & 0.85 & 0.36 & 0.9 & 0.3 & 0.88 & 0.33 \\
\hline Capreached & 0.41 & 0.49 & 0.48 & 0.50 & 0.41 & 0.49 & 0.27 & 0.45 & 0.22 & 0.42 \\
\hline
\end{tabular}

Note. The number of observations for non-U.S. citizens $(2,449)$ does not equal the sum of observations for work visa and green card holders $(818+862=1,680)$ because work visa and green card information is available for years $2000-2003$ only.

questions allow a binary (yes or no) response. It is possible for a respondent to indicate "no" to both of these questions, and we used such a response to categorize these respondent as green card holders because green card holders as permanent residents are neither U.S. citizens nor on a work visa. Although some IT professionals (close to 1\%) in our data set are contract employees, to ensure comparability of results, we restricted the analyses to full-time IT professionals.

Table 2 provides descriptive statistics comparing the data along U.S. citizenship status, work visa status, and green card status, respectively. Table 2 shows that in terms of respondents' highest degrees, $4 \%$ of non-U.S. citizens have a Ph.D. compared to $2 \%$ for U.S. citizens in our sample. Likewise, 38\% of non-U.S. citizens have a master's degree (including MBA), whereas only $21 \%$ of U.S. citizens have a master's degree. These summary statistics support the belief that foreign IT professionals are more likely to have higher education than American IT professionals, and it also lends credence to the shortage of highly educated American IT professionals reported by IT companies to argue support for higher visa caps (Thibodeau 2008). In terms of experience, U.S. citizens have higher total experience and IT experience than non-U.S. citizens. The proportion of non-U.S. citizens is higher in IT, IT-intensive, and dot-com firms and lower in nonprofits and the government sector compared to that of U.S. citizens. Because of these differences in human capital attributes and institutional characteristics, comparing means of compensation by citizenship or visa status can be misleading. ${ }^{5}$

Table 3 reports correlations among variables. In general, all the correlations have expected signs and none is so large to cause any concerns about multicollinearity.

\subsection{Empirical Models and Econometric Issues}

One of the major strengths of this study is use of individual-level microdata, which offers several advantages compared to prior empirical studies that used aggregate data at the area, occupation, experience, and education group levels. For example, crossarea studies relate wages in an area (e.g., city or region) with immigrant density in that area (Butcher and Card 1991). These studies suffer from endogeneity problems in open economic environments if immigrants migrate to higher-wage areas and/or if natives react to these movements, or there are changes in industry mix. Likewise, within-occupation or withinskill group studies that relate immigrant inflows

\footnotetext{
${ }^{5}$ Nonetheless, we do not find any economically significant differences when we conduct $t$-tests for differences in compensation and hours of work of professionals with U.S. citizenship vis-à-vis those without citizenship, although the differences are statistically significant because of a large sample size. The finding that on average foreign IT workers report working about the same hours as American workers fails to support the observation that firms exploit foreign IT workers and make them work more (see Matloff 2003). We see broadly similar patterns when we compare IT professionals on $\mathrm{H}-1 \mathrm{~B}$ or other work visas or IT professionals with a green card with IT professionals having U.S. citizenship.
} 
Table 3

Correlations Among Variables

\begin{tabular}{|c|c|c|c|c|c|c|c|c|c|c|c|c|c|c|c|c|c|c|c|}
\hline & 1 & 2 & 3 & 4 & 5 & 6 & 7 & 8 & 9 & 10 & 11 & 12 & 13 & 14 & 15 & 16 & 17 & 18 & 19 \\
\hline 1 Lncashcomp & 1.00 & & & & & & & & & & & & & & & & & & \\
\hline 2 Eduphd & 0.08 & 1.00 & & & & & & & & & & & & & & & & & \\
\hline 3 Edumba & 0.17 & -0.04 & 1.00 & & & & & & & & & & & & & & & & \\
\hline 4 Edumaster & 0.14 & -0.05 & -0.12 & 1.00 & & & & & & & & & & & & & & & \\
\hline 5 Edubach & 0.05 & -0.12 & -0.25 & -0.37 & 1.00 & & & & & & & & & & & & & & \\
\hline 6 Edusomecoll & -0.12 & -0.05 & -0.11 & -0.17 & -0.37 & 1.00 & & & & & & & & & & & & & \\
\hline 7 Itexpcurrco & 0.14 & 0.02 & 0.01 & 0.02 & 0.00 & -0.02 & 1.00 & & & & & & & & & & & & \\
\hline 8 Itexpothercos & 0.31 & 0.02 & 0.05 & 0.04 & -0.04 & -0.01 & -0.24 & 1.00 & & & & & & & & & & & \\
\hline 9 Totexp & 0.16 & 0.00 & -0.01 & 0.00 & -0.12 & 0.04 & 0.40 & 0.41 & 1.00 & & & & & & & & & & \\
\hline 10 Itind & 0.13 & 0.00 & 0.00 & 0.02 & 0.01 & 0.00 & -0.08 & 0.02 & -0.10 & 1.00 & & & & & & & & & \\
\hline 11 Dot-com & 0.06 & 0.01 & 0.00 & 0.01 & 0.00 & 0.01 & -0.11 & 0.03 & -0.09 & 0.19 & & & & & & & & & \\
\hline 12 Hiit & 0.19 & -0.01 & 0.03 & 0.00 & 0.03 & 0.00 & -0.12 & 0.05 & -0.12 & 0.44 & 0.11 & 1.00 & & & & & & & \\
\hline 13 Empno & 0.19 & 0.00 & 0.07 & 0.05 & 0.03 & -0.06 & 0.20 & 0.00 & 0.07 & 0.01 & -0.17 & 0.02 & 1.00 & & & & & & \\
\hline $14 \mathrm{Npg}$ & -0.12 & 0.01 & -0.04 & 0.02 & -0.01 & 0.00 & 0.07 & 0.01 & 0.12 & -0.18 & -0.06 & -0.36 & -0.04 & 1.00 & & & & & \\
\hline 15 Hrsperwk & 0.28 & 0.03 & 0.05 & 0.02 & -0.03 & 0.03 & -0.02 & 0.10 & 0.03 & 0.08 & 0.08 & 0.07 & -0.03 & -0.12 & 1.00 & & & & \\
\hline 16 Male & 0.10 & 0.01 & 0.00 & -0.02 & 0.01 & 0.00 & -0.02 & 0.06 & -0.03 & 0.04 & 0.02 & 0.02 & 0.00 & -0.03 & 0.06 & 1.00 & & & \\
\hline 17 Capreached & 0.01 & 0.01 & -0.02 & 0.01 & 0.00 & 0.01 & 0.00 & -0.01 & -0.02 & 0.02 & 0.02 & 0.00 & -0.01 & 0.00 & -0.02 & 0.00 & 1.00 & & \\
\hline 18 Nonuscit & 0.06 & 0.04 & 0.01 & 0.10 & -0.01 & -0.05 & -0.08 & -0.02 & -0.14 & 0.09 & 0.04 & 0.07 & -0.01 & -0.05 & -0.01 & 0.02 & 0.03 & 1.00 & \\
\hline $19 H 1 b$ & 0.03 & 0.01 & 0.00 & 0.05 & 0.01 & -0.04 & -0.06 & -0.02 & -0.11 & 0.09 & 0.03 & 0.06 & -0.01 & -0.03 & 0.01 & 0.02 & -0.04 & 0.57 & 1.00 \\
\hline 20 Green card & 0.04 & 0.03 & 0.00 & 0.05 & -0.02 & -0.02 & -0.04 & -0.01 & -0.06 & 0.03 & 0.02 & 0.03 & 0.00 & -0.03 & 0.00 & 0.01 & -0.05 & 0.58 & -0.02 \\
\hline
\end{tabular}

to occupational, skill, or education group wages (Borjas 2003, Card 2001, Friedberg 2001, Orrenius and Zavodny 2007) also suffer from endogeneity due to immigrants settling in higher-wage areas. Some researchers use an instrumental variables approach to deal with these endogeneity problems (Orrenius and Zavodny 2007), whereas other studies use "natural experiments" in which location or timing of immigration is politically (and less so economically) motivated, reducing the problem of immigrants choosing location based on market conditions (Card 1990, Hunt 1992). Very few studies (Chiswick 1978, LaLonde and Topel 1991 are some exceptions) use microdata on compensation of immigrants and natives to relate immigration with wages. These microstudies are less susceptible to some of the endogeneity problems that affect area or occupation level studies, particularly if they use an array of control variables at the individual level (see Friedberg and Hunt 1995 for a discussion). Our study, using microdata on IT professionals and including a rich array of control variables, has the added advantage of using a natural experiment because of congressionally mandated changes in visa caps.

Following previous research in the labor economics and information systems literature (Ang et al. 2002, Angrist and Krueger 1999, Mithas and Krishnan 2008), we specify a standard cross-sectional log-linear earnings model to estimate the effect of citizenship and work visa status on compensation. Let $W$ represent the annual salary of the respondent; $X$ and $Z$ are vectors of observed characteristics associated with the respondent and the institutional context, respectively; and $V$ represents the citizenship or work visa status of a respondent $(V=1$ for non-U.S. citizens, $H-1 B$ or other work visa holders, and green card holders depending on the context, 0 otherwise). ${ }^{6}$

$$
\ln W_{i}=\alpha V_{i}+\beta X_{i}+\gamma Z_{i}+\delta V_{i} X_{i}+\varepsilon_{i}
$$

where $\alpha, \beta, \gamma$, and $\delta$ are the parameters to be estimated, and $\varepsilon$ is the error term associated with observation $i$.

Tables 4 and 5 report the results of fitting (1) by ordinary least squares. We present models in Table 4 in a hierarchical manner, first showing a model with control variables only (see column (1)) and then introducing our focal variables in columns (2) and (3) of Table 4 . The explanatory power of our models, as reflected by the overall $R$-square values, is reasonable and comparable to that in previous research (e.g., Krueger 1993). We checked for multicollinearity, and mean variance inflation factor values in the models were generally less than 5 , and all coefficients were in the expected direction, suggesting that multicollinearity is not a serious concern. Because of the presence of IT professionals across a variety of U.S. states and industries, there is a potential for heteroskedastic variance. We conducted a BreuschPagan test, which showed evidence for heteroskedasticity in our data (chi-squared statistic $=136.68$ for $\mathrm{df}=1, p$ value for the chi-squared statistic $<0.01$ ). We, therefore, accounted for heteroskedasticity and report heteroskedasticity-consistent standard errors in our models.

\footnotetext{
${ }^{6}$ Because U.S. citizens also include some foreign-born naturalized citizens, the salary premiums due to citizenship or visa status in this study provide a conservative or lower bound estimate.
} 
Table 4 How Citizenship and Visa Status Affect Compensation of IT Professionals (Dependent Variable Is Natural Log of Cash Compensation)

\begin{tabular}{|c|c|c|c|}
\hline & (1) & (2) & (3) \\
\hline Non-U.S. citizen & & $\begin{array}{l}0.085^{* * *} \\
(0.008)\end{array}$ & \\
\hline$H-1 B$ & & & $\begin{array}{l}0.066^{* * *} \\
(0.012)\end{array}$ \\
\hline Green card & & & $\begin{array}{l}0.122^{* * *} \\
(0.012)\end{array}$ \\
\hline Ph.D. & $\begin{array}{l}0.397^{* * *} \\
(0.014)\end{array}$ & $\begin{array}{l}0.391^{* * *} \\
(0.014)\end{array}$ & $\begin{array}{l}0.392^{* * *} \\
(0.014)\end{array}$ \\
\hline$M B A$ & $\begin{array}{l}0.375^{* * *} \\
(0.007)\end{array}$ & $\begin{array}{l}0.374^{* * *} \\
(0.007)\end{array}$ & $\begin{array}{l}0.375^{* * *} \\
(0.007)\end{array}$ \\
\hline Master's degree & $\begin{array}{l}0.296^{* * *} \\
(0.006)\end{array}$ & $\begin{array}{l}0.291^{* * *} \\
(0.006)\end{array}$ & $\begin{array}{l}0.292^{* * *} \\
(0.006)\end{array}$ \\
\hline Bachelor's degree & $\begin{array}{l}0.202^{* * * *} \\
(0.004)\end{array}$ & $\begin{array}{l}0.202^{* * *} \\
(0.004)\end{array}$ & $\begin{array}{l}0.202^{* * *} \\
(0.004)\end{array}$ \\
\hline Some college & $\begin{array}{l}0.058^{* * *} \\
(0.006)\end{array}$ & $\begin{array}{l}0.059^{* * *} \\
(0.006)\end{array}$ & $\begin{array}{l}0.059^{* * *} \\
(0.006)\end{array}$ \\
\hline Firm-specific IT experience & $\begin{array}{l}0.024^{* * *} \\
(0.001)\end{array}$ & $\begin{array}{l}0.024^{* * *} \\
(0.001)\end{array}$ & $\begin{array}{l}0.024^{* * *} \\
(0.001)\end{array}$ \\
\hline General IT experience & $\begin{array}{l}0.036^{* * *} \\
(0.001)\end{array}$ & $\begin{array}{c}0.036^{* * *} \\
(0.001)\end{array}$ & $\begin{array}{l}0.036^{* * *} \\
(0.001)\end{array}$ \\
\hline Total experience & $\begin{array}{c}-0.000 \\
(0.000)\end{array}$ & $\begin{array}{c}0.000 \\
(0.000)\end{array}$ & $\begin{array}{c}0.000 \\
(0.000)\end{array}$ \\
\hline Male & $\begin{array}{l}0.081^{* * *} \\
(0.004)\end{array}$ & $\begin{array}{l}0.080^{* * *} \\
(0.004)\end{array}$ & $\begin{array}{l}0.081^{\text {*** }} \\
(0.004)\end{array}$ \\
\hline Firm size & $\begin{array}{l}0.051^{* * *} \\
(0.002)\end{array}$ & $\begin{array}{l}0.051^{* * *} \\
(0.002)\end{array}$ & $\begin{array}{l}0.051^{* * *} \\
(0.002)\end{array}$ \\
\hline Nonprofit and govt. sector & $\begin{array}{c}-0.049 * * * \\
(0.005)\end{array}$ & $\begin{array}{c}-0.047^{* * *} \\
(0.005)\end{array}$ & $\begin{array}{c}-0.048^{* * *} \\
(0.005)\end{array}$ \\
\hline IT industry & $\begin{array}{l}0.035^{* * * *} \\
(0.004)\end{array}$ & $\begin{array}{l}0.032^{* * *} \\
(0.004)\end{array}$ & $\begin{array}{l}0.033^{* * * *} \\
(0.004)\end{array}$ \\
\hline Dot-com firm & $\begin{array}{l}0.106^{* * *} \\
(0.008)\end{array}$ & $\begin{array}{l}0.105^{* * *} \\
(0.008)\end{array}$ & $\begin{array}{l}0.105^{* * *} \\
(0.008)\end{array}$ \\
\hline IT-intensive industry & $\begin{array}{l}0.109^{* * *} \\
(0.004)\end{array}$ & $\begin{array}{l}0.109^{* * *} \\
(0.004)\end{array}$ & $\begin{array}{l}0.109^{* * *} \\
(0.004)\end{array}$ \\
\hline Year 2001 & $\begin{array}{c}-0.040^{* * *} \\
(0.005)\end{array}$ & $\begin{array}{c}-0.040^{* * *} \\
(0.005)\end{array}$ & $\begin{array}{c}-0.040 * * * \\
(0.005)\end{array}$ \\
\hline Year 2002 & $\begin{array}{c}-0.072^{* * *} \\
(0.005)\end{array}$ & $\begin{array}{c}-0.072^{* * *} \\
(0.005)\end{array}$ & $\begin{array}{c}-0.072^{* * *} \\
(0.005)\end{array}$ \\
\hline Year 2003 & $\begin{array}{c}-0.065^{* * *} \\
(0.005)\end{array}$ & $\begin{array}{c}-0.066 \text { *** } \\
(0.005)\end{array}$ & $\begin{array}{c}-0.066^{* * *} \\
(0.005)\end{array}$ \\
\hline Year 2004 & $\begin{array}{c}-0.063^{* * *} \\
(0.011)\end{array}$ & $\begin{array}{c}-0.068^{* * *} \\
(0.011)\end{array}$ & $\begin{array}{c}-0.060^{\text {*** }} \\
(0.011)\end{array}$ \\
\hline Year 2005 & $-0.087^{* * *}$ & $-0.089^{* * *}$ & $-0.084^{* * *}$ \\
\hline Observations & 51,363 & 51,363 & 51,316 \\
\hline$R$-squared & 0.360 & 0.361 & 0.361 \\
\hline F statistic & $1,225.81^{* * *}$ & $1,180.53^{* * *}$ & $1,132.37^{* * *}$ \\
\hline df & 51,340 & 51,339 & 51,291 \\
\hline
\end{tabular}

Notes. Visa and green card status is not available for 2004-2005. All the models include an intercept term, hours per week, and squared terms for IT experience at current firm and IT experience at other firms.

${ }^{* * *} p<0.01$. Robust standard errors are in parentheses.
Table 5 How Visa Caps Affect Wage Differences in Compensation of Foreign and American IT Professionals (Dependent Variable Is Natural Log of Cash Compensation)

\begin{tabular}{|c|c|c|}
\hline & (1) & (2) \\
\hline$H-1 B$ & $\begin{array}{l}0.066^{* * *} \\
(0.012)\end{array}$ & $\begin{array}{l}0.051^{* * *} \\
(0.014)\end{array}$ \\
\hline Green card & $\begin{array}{l}0.122^{* * *} \\
(0.012)\end{array}$ & $\begin{array}{l}0.115^{* * *} \\
(0.013)\end{array}$ \\
\hline Capreached & $\begin{array}{l}0.040^{* * *} \\
(0.005)\end{array}$ & $\begin{array}{l}0.038^{* * *} \\
(0.005)\end{array}$ \\
\hline Capreached $\times$ green card & & $\begin{array}{c}0.031 \\
(0.031)\end{array}$ \\
\hline Capreached $\times H-1 B$ & & $\begin{array}{c}0.055^{* *} \\
(0.026)\end{array}$ \\
\hline Ph.D. & $\begin{array}{l}0.392^{* * *} \\
(0.014)\end{array}$ & $\begin{array}{l}0.392^{* * *} \\
(0.014)\end{array}$ \\
\hline$M B A$ & $\begin{array}{l}0.375^{* * *} \\
(0.007)\end{array}$ & $\begin{array}{l}0.374^{* * *} \\
(0.007)\end{array}$ \\
\hline Master's degree & $\begin{array}{l}0.292^{* * *} \\
(0.006)\end{array}$ & $\begin{array}{l}0.292^{* * *} \\
(0.006)\end{array}$ \\
\hline Bachelor's degree & $\begin{array}{l}0.202^{* * *} \\
(0.004)\end{array}$ & $\begin{array}{l}0.202^{* * *} \\
(0.004)\end{array}$ \\
\hline Some college & $\begin{array}{l}0.059^{* * *} \\
(0.006)\end{array}$ & $\begin{array}{l}0.059^{* * *} \\
(0.006)\end{array}$ \\
\hline Firm-specific IT experience & $\begin{array}{l}0.024^{* * *} \\
(0.001)\end{array}$ & $\begin{array}{l}0.024^{* * *} \\
(0.001)\end{array}$ \\
\hline General IT experience & $\begin{array}{l}0.036^{* * *} \\
(0.001)\end{array}$ & $\begin{array}{l}0.036 * * * \\
(0.001)\end{array}$ \\
\hline Total experience & $\begin{array}{c}0.000 \\
(0.000)\end{array}$ & $\begin{array}{c}0.000 \\
(0.000)\end{array}$ \\
\hline Male & $\begin{array}{l}0.081^{* * *} \\
(0.004)\end{array}$ & $\begin{array}{l}0.081^{* * *} \\
(0.004)\end{array}$ \\
\hline Firm size & $\begin{array}{l}0.051^{* * *} \\
(0.002)\end{array}$ & $\begin{array}{l}0.051^{* * *} \\
(0.002)\end{array}$ \\
\hline Nonprofit and govt. sector & $\begin{array}{c}-0.048^{* * *} \\
(0.005)\end{array}$ & $\begin{array}{c}-0.048^{* * *} \\
(0.005)\end{array}$ \\
\hline IT industry & $\begin{array}{l}0.033^{* * *} \\
(0.004)\end{array}$ & $\begin{array}{l}0.033^{* * *} \\
(0.004)\end{array}$ \\
\hline Dot-com firm & $\begin{array}{l}0.105^{* * *} \\
(0.008)\end{array}$ & $\begin{array}{l}0.105^{* * *} \\
(0.008)\end{array}$ \\
\hline IT-intensive industry & $\begin{array}{l}0.109^{* * *} \\
(0.004)\end{array}$ & $\begin{array}{l}0.109^{* * *} \\
(0.004)\end{array}$ \\
\hline Year 2002 & $\begin{array}{c}-0.032^{* * *} \\
(0.005)\end{array}$ & $\begin{array}{c}-0.032^{* * *} \\
(0.005)\end{array}$ \\
\hline Year 2003 & $\begin{array}{c}-0.026^{* * *} \\
(0.005)\end{array}$ & $\begin{array}{c}-0.026^{* * *} \\
(0.005)\end{array}$ \\
\hline Year 2004 & $\begin{array}{c}-0.060^{* * *} \\
(0.011)\end{array}$ & $\begin{array}{c}-0.059^{* * *} \\
(0.011)\end{array}$ \\
\hline Year 2005 & $\begin{array}{c}-0.084^{* * *} \\
(0.005)\end{array}$ & $\begin{array}{c}-0.082^{* * *} \\
(0.005)\end{array}$ \\
\hline Observations & 51,316 & 51,316 \\
\hline$R$-squared & 0.3611 & 0.3612 \\
\hline F statistic & $1,132.37^{* * *}$ & $1,045.71^{\text {*** }}$ \\
\hline df & 51,291 & 51,289 \\
\hline
\end{tabular}

Notes. Visa and green card status is not available for 2004-2005. All the models use an intercept term, hours per week, and squared terms for IT experience at current firm and IT experience at other firms.

${ }^{* *} p<0.05 ;{ }^{* * *} p<0.01$. Robust standard errors are in parentheses. 


\section{Results}

\subsection{Relative Wages of Foreign and American IT Professionals}

Hypothesis 1A predicted that after accounting for educational qualifications, work experience, and relevant controls, IT professionals without U.S. citizenship will have a salary premium compared to IT professionals with U.S. citizenship. As column (2) of Table 4 shows, we find support for this hypothesis because IT professionals without U.S. citizenship earn $8.9 \%$ more than those with U.S. citizenship, and this difference is statistically significant $(p<0.001){ }^{7}$ Hypothesis 1B predicted that after accounting for educational qualifications, work experience, and relevant controls, IT professionals with an $\mathrm{H}-1 \mathrm{~B}$ or other work visa will have a salary premium compared to IT professionals who have U.S. citizenship. We find support for this hypothesis; IT professionals on H-1B or other work visas earn $6.8 \%$ more than those with U.S. citizenship, and this difference is statistically significant (Table 4 , column (3); $p<0.001$ ). Hypothesis $1 C$ predicted that after accounting for educational qualifications, work experience, and relevant controls, IT professionals with green card status will have a salary premium compared to those with U.S. citizenship or a work visa. We find support for this hypothesis because IT professionals with a green card earn $12.9 \%$ more than those with a U.S. citizenship, and this difference is statistically significant $(p<0.001)$. We also tested whether green card holders have a salary premium compared to those with an $\mathrm{H}-1 \mathrm{~B}$ or some other work visa. An IT professional with a green card earns $6.1 \%$ more than one with a work visa, and the difference in coefficients of a green card holder versus a work visa holder is positive and statistically significant (Wald test, $F=11.52, p<0.001$ ).

\subsection{How H-1B Visa Caps Affect Compensation}

Hypothesis 2 relates the effect of supply-side visa and immigration policies to the wages of foreign and American IT professionals. Table 5 provides results to quantify the impact of setting lower visa caps on compensation of foreign and American professionals. We include an indicator variable (i.e., Capreached) in the models indicating that the visa cap was fully utilized that year, and we also include interaction terms involving this dummy with citizenship and visa status. We find support for $\mathrm{H} 2$ because the coefficient of the interaction term involving visa cap utilization and visa (i.e., H-1B) status is positive and statistically significant, suggesting that lower and fully utilized visa

\footnotetext{
${ }^{7}$ The coefficient for nonuscit in column (2) of Table 4 is 0.085 . The value of e raised to 0.085 is 1.089 , which means that a unit change in nonuscit is associated with a change of 1.089 in $W$, or $8.9 \%$ wage premium all else constant.
}

caps increase the salary premium for $\mathrm{H}-1 \mathrm{~B}$ professionals. In contrast, the coefficient of the interaction term involving visa cap utilization and green card is statistically insignificant, suggesting that visa caps have no effect on salary premiums of green card holders.

We conducted additional analyses using yearwise regressions and found that non-U.S. citizens earned statistically significant salary premiums from 2000 to 2005, after controlling for education, experience, demographic, and other institutional variables deemed important in prior research (see Table 6). The salary premium is $10.6 \%$ in $2000,8.1 \%$ in $2001,11.1 \%$ in $2002,8.3 \%$ in $2003,17.5 \%$ in 2004 , and $4.7 \%$ in 2005. Note that during 2001 to 2003, actual H-1B visas issued were lower than the maximum limit of 195,000 allowed by the H-1B, cap, and yet we observe salary premiums for non-U.S. citizen IT professionals during these years. During 2004, maximum quotas came down to pre-1999 levels of 65,000, and perhaps as a result, the premium rose significantly that year. During 2005, Congress allowed an additional 20,000 H-1B work visas for foreign professionals graduating from U.S. universities, and we see some impact in the form of lower salary premium during that year.

We further divided the non-U.S. citizen category into work visa and green card status categories for which we have data from 2000 to 2003 (see Table 7). We find that the salary premium is $8.4 \%$ in $2000,3.3 \%$ in $2001,8.4 \%$ in 2002, and $4.4 \%$ in 2003 for H-1B holders. In contrast, the salary premium for green card holders is generally higher than that for work visa holders during these years (green card premiums are $13.9 \%$ in $2000,12.9 \%$ in $2001,13.6 \%$ in 2002 , and $11 \%$ in 2003). ${ }^{8}$ Figure 4 shows yearwise salary premiums for IT professionals with an H-1B or other work visa, IT professionals with a green card and non-U.S. citizen IT professionals from 2000 to 2005. Interestingly, the salary premiums for non-U.S. citizens, H-1B or other work visa holders, and green card holders rise or fall in concert and are generally higher when the $\mathrm{H}-1 \mathrm{~B}$ visa cap is lower and fully utilized as predicted by the reasoning for $\mathrm{H} 2$.

On the whole, the yearwise results on salary premium for foreign professionals do not provide support for the notion that firms are misusing U.S. work visa provisions to pay less to foreign professionals. The presence of a significant salary premium for $\mathrm{H}-1 \mathrm{~B}$ and other visa holders in 2000 when the H-1B cap was 115,000, but insignificant premium in 2001 when the H-1B cap went up to 195,000 , appears to vindicate the IT industry's plea for raising the H-1B cap

\footnotetext{
${ }^{8}$ Because of reduced sample size and statistical power in the yearly regressions, the statistical significance of the green card and $H-1 B$ coefficients and the differences among them is lower than that in results using full sample size across all the years as in Tables 4 and 5 .
} 
Table 6 Yearwise Compensation Regressions for Non-U.S. Citizenship Premium (Dependent Variable Is Natural Log of Cash Compensation)

\begin{tabular}{|c|c|c|c|c|c|c|}
\hline & $(1)$ & $(2)$ & (3) & (4) & $(5)$ & (6) \\
\hline & 2000 & 2001 & 2002 & 2003 & 2004 & 2005 \\
\hline Non-U.S. citizen & $\begin{array}{l}0.101^{\text {**** }} \\
(0.018)\end{array}$ & $\begin{array}{l}0.078^{* * *} \\
(0.020)\end{array}$ & $\begin{array}{l}0.106^{* * *} \\
(0.016)\end{array}$ & $\begin{array}{l}0.079 * * * \\
(0.016)\end{array}$ & $\begin{array}{l}0.162^{* * *} \\
(0.047)\end{array}$ & $\begin{array}{l}0.046^{* * *} \\
(0.016)\end{array}$ \\
\hline Ph.D. & $\begin{array}{l}0.453^{* * *} \\
(0.033)\end{array}$ & $\begin{array}{l}0.322^{* * *} \\
(0.037)\end{array}$ & $\begin{array}{l}0.381^{* * *} \\
(0.031)\end{array}$ & $\begin{array}{l}0.405^{* * *} \\
(0.028)\end{array}$ & $\begin{array}{l}0.447^{* * *} \\
(0.077)\end{array}$ & $\begin{array}{c}0.388^{* * *} \\
(0.032)\end{array}$ \\
\hline$M B A$ & $\begin{array}{l}0.370^{* * *} \\
(0.018)\end{array}$ & $\begin{array}{l}0.400^{* * *} \\
(0.018)\end{array}$ & $\begin{array}{l}0.360^{* * *} \\
(0.014)\end{array}$ & $\begin{array}{l}0.383^{* * *} \\
(0.015)\end{array}$ & $\begin{array}{l}0.331^{* * *} \\
(0.046)\end{array}$ & $\begin{array}{l}0.388^{* * *} \\
(0.017)\end{array}$ \\
\hline Master's degree & $\begin{array}{l}0.291^{* * *} \\
(0.014)\end{array}$ & $\begin{array}{l}0.297^{* * *} \\
(0.014)\end{array}$ & $\begin{array}{l}0.266^{* * *} \\
(0.010)\end{array}$ & $\begin{array}{l}0.304^{* * *} \\
(0.012)\end{array}$ & $\begin{array}{l}0.280^{* * *} \\
(0.037)\end{array}$ & $\begin{array}{c}0.311^{* * *} \\
(0.013)\end{array}$ \\
\hline Bachelor's degree & $\begin{array}{l}0.186^{* * *} \\
(0.010)\end{array}$ & $\begin{array}{l}0.199^{* * *} \\
(0.011)\end{array}$ & $\begin{array}{l}0.187^{* * *} \\
(0.008)\end{array}$ & $\begin{array}{l}0.224^{* * *} \\
(0.010)\end{array}$ & $\begin{array}{l}0.224^{* * *} \\
(0.033)\end{array}$ & $\begin{array}{l}0.215^{* * *} \\
(0.011)\end{array}$ \\
\hline Some college & $\begin{array}{l}0.050^{* * *} \\
(0.012)\end{array}$ & $\begin{array}{l}0.061^{* * *} \\
(0.013)\end{array}$ & $\begin{array}{l}0.035^{* * *} \\
(0.011)\end{array}$ & $\begin{array}{l}0.074^{* * *} \\
(0.013)\end{array}$ & $\begin{array}{l}0.115^{* * *} \\
(0.039)\end{array}$ & $\begin{array}{l}0.074^{* * *} \\
(0.014)\end{array}$ \\
\hline Firm-specific IT experience & $\begin{array}{l}0.021^{* * *} \\
(0.002)\end{array}$ & $\begin{array}{l}0.023^{* * *} \\
(0.002)\end{array}$ & $\begin{array}{l}0.026^{* * *} \\
(0.002)\end{array}$ & $\begin{array}{l}0.023^{* * *} \\
(0.002)\end{array}$ & $\begin{array}{l}0.025^{* * *} \\
(0.005)\end{array}$ & $\begin{array}{l}0.028^{* * *} \\
(0.002)\end{array}$ \\
\hline General IT experience & $\begin{array}{c}0.039 * * * \\
(0.001)\end{array}$ & $\begin{array}{l}0.039^{* * *} \\
(0.002)\end{array}$ & $\begin{array}{l}0.036^{* * *} \\
(0.001)\end{array}$ & $\begin{array}{c}0.033^{* * *} \\
(0.001)\end{array}$ & $\begin{array}{l}0.040^{* * *} \\
(0.003)\end{array}$ & $\begin{array}{l}0.032^{* * *} \\
(0.001)\end{array}$ \\
\hline Total experience & $\begin{array}{c}-0.001 \\
(0.001)\end{array}$ & $\begin{array}{c}0.000 \\
(0.001)\end{array}$ & $\begin{array}{c}0.000 \\
(0.000)\end{array}$ & $\begin{array}{c}-0.000 \\
(0.001)\end{array}$ & $\begin{array}{c}-0.002 \\
(0.002)\end{array}$ & $\begin{array}{l}0.001^{* *} \\
(0.001)\end{array}$ \\
\hline Male & $\begin{array}{c}0.078^{* * *} \\
(0.010)\end{array}$ & $\begin{array}{l}0.081^{* * *} \\
(0.011)\end{array}$ & $\begin{array}{l}0.079 * * * \\
(0.008)\end{array}$ & $\begin{array}{c}0.083^{* * *} \\
(0.009)\end{array}$ & $\begin{array}{c}0.047^{*} \\
(0.026)\end{array}$ & $\begin{array}{c}0.090^{* * *} \\
(0.010)\end{array}$ \\
\hline Firm size & $\begin{array}{l}0.058^{* * *} \\
(0.004)\end{array}$ & $\begin{array}{l}0.042^{* * *} \\
(0.004)\end{array}$ & $\begin{array}{l}0.052^{* * *} \\
(0.003)\end{array}$ & $\begin{array}{l}0.048^{* * *} \\
(0.003)\end{array}$ & $\begin{array}{l}0.045^{* * *} \\
(0.011)\end{array}$ & $\begin{array}{l}0.057^{* * *} \\
(0.004)\end{array}$ \\
\hline Nonprofit and govt. sector & $\begin{array}{c}-0.049^{* * *} \\
(0.012)\end{array}$ & $\begin{array}{c}-0.040^{* * *} \\
(0.013)\end{array}$ & $\begin{array}{c}-0.056^{* * *} \\
(0.009)\end{array}$ & $\begin{array}{c}-0.062^{* * *} \\
(0.011)\end{array}$ & $\begin{array}{c}0.002 \\
(0.028)\end{array}$ & $\begin{array}{c}-0.041^{* * *} \\
(0.011)\end{array}$ \\
\hline IT industry & $\begin{array}{l}0.037^{* * *} \\
(0.010)\end{array}$ & $\begin{array}{l}0.032^{* * *} \\
(0.011)\end{array}$ & $\begin{array}{l}0.026^{* * *} \\
(0.009)\end{array}$ & $\begin{array}{c}0.015 \\
(0.010)\end{array}$ & $\begin{array}{c}-0.020 \\
(0.034)\end{array}$ & $\begin{array}{c}0.039 * * * \\
(0.011)\end{array}$ \\
\hline Dot-com firm & $\begin{array}{l}0.155^{* * *} \\
(0.017)\end{array}$ & $\begin{array}{c}0.026 \\
(0.017)\end{array}$ & $\begin{array}{l}0.084^{* * *} \\
(0.018)\end{array}$ & $\begin{array}{l}0.120^{* * *} \\
(0.021)\end{array}$ & $\begin{array}{c}0.074 \\
(0.053)\end{array}$ & $\begin{array}{c}0.131^{* * *} \\
(0.022)\end{array}$ \\
\hline IT-intensive industry & $\begin{array}{l}0.139^{* * * *} \\
(0.010)\end{array}$ & $\begin{array}{l}0.136^{* * *} \\
(0.010)\end{array}$ & $\begin{array}{l}0.089^{* * *} \\
(0.008)\end{array}$ & $\begin{array}{l}0.086^{* * *} \\
(0.008)\end{array}$ & $\begin{array}{l}0.097^{* * *} \\
(0.022)\end{array}$ & $\begin{array}{l}0.114^{* * *} \\
(0.008)\end{array}$ \\
\hline Observations & 9,235 & 7,722 & 12,820 & 9,816 & 2,031 & 9,739 \\
\hline$R$-squared & 0.393 & 0.379 & 0.373 & 0.362 & 0.247 & 0.346 \\
\hline F statistic & $305.26^{* * *}$ & $251.45^{* * *}$ & $406.21^{* * *}$ & $299.31^{* * *}$ & $30.75^{* * *}$ & $262.46^{* * *}$ \\
\hline df & 9,216 & 7,704 & 12,801 & 9,797 & 2,012 & 9,720 \\
\hline
\end{tabular}

Note. All the models use an intercept term, hours per week, and squared terms for IT experience at current firm and IT experience at other firms. ${ }^{*} p<0.1 ;{ }^{* *} p<0.05 ;{ }^{* * *} p<0.01$. Robust standard errors are in parentheses.

to make it easier to hire foreign professionals to overcome "tightness" in the IT labor market (Thibodeau 2008). Although the H-1B cap remained underutilized during 2002 and 2003, the H-1B salary premium during these years lends support to foreign IT professionals as being complements rather than substitutes for American professionals.

Collectively, the presence of salary premiums for foreign professionals even when a visa cap is underutilized and the fact that $\mathrm{H}-1 \mathrm{~B}$ professionals' salary premiums are more directly affected by $\mathrm{H}-1 \mathrm{~B}$ visa restrictions than that of green card holders imply that (1) foreign IT professionals are complements of American IT professionals, and (2) H-1B professionals may be substitutes for each other because a reduction in their supply affects their wages much more than that of green card holders. This finding is consistent with anecdotal evidence in trade press that suggests substitution among visa holders (Thibodeau 2009).

\subsection{Additional Analyses and Robustness Checks}

We now discuss additional analyses and robustness checks to rule out some alternative explanations for our findings. First, our results are not driven by foreign IT professionals self-selecting and migrating to high-paying areas because our main findings hold even if we control for location of IT professionals at the U.S. state level in our models. Including dummies for states results in premiums that are lower by $1 \%-3 \%$, though still sizable (see Table 8 , column (2)). Note also that migration to high-paying areas is not completely under the control of IT professionals; employers need to offer jobs in those areas based on their assessment of skills and competencies of IT 
Table 7 Yearwise Compensation Regressions for H-1B and Green Card Premium (Dependent Variable Is Natural Log of Cash Compensation; Visa and Green Card Status Is Not Available for 2004-2005)

\begin{tabular}{|c|c|c|c|c|}
\hline & (1) & (2) & (3) & (4) \\
\hline & 2000 & 2001 & 2002 & 2003 \\
\hline$H-1 B$ & $\begin{array}{l}0.080^{* * *} \\
(0.023)\end{array}$ & $\begin{array}{c}0.032 \\
(0.026)\end{array}$ & $\begin{array}{l}0.081^{* * *} \\
(0.022)\end{array}$ & $\begin{array}{c}0.043^{*} \\
(0.024)\end{array}$ \\
\hline Green card & $\begin{array}{c}0.130^{* * *} \\
(0.027)\end{array}$ & $\begin{array}{l}0.121^{* * *} \\
(0.027)\end{array}$ & $\begin{array}{l}0.127^{* * *} \\
(0.022)\end{array}$ & $\begin{array}{l}0.104^{* * *} \\
(0.020)\end{array}$ \\
\hline Ph.D. & $\begin{array}{l}0.452^{* * *} \\
(0.033)\end{array}$ & $\begin{array}{l}0.322^{* * *} \\
(0.037)\end{array}$ & $\begin{array}{l}0.381^{* * *} \\
(0.031)\end{array}$ & $\begin{array}{c}0.404^{* * *} \\
(0.028)\end{array}$ \\
\hline MBA & $\begin{array}{l}0.372^{* * *} \\
(0.017)\end{array}$ & $\begin{array}{l}0.400^{* * *} \\
(0.018)\end{array}$ & $\begin{array}{l}0.360^{* * *} \\
(0.014)\end{array}$ & $\begin{array}{l}0.383^{* * *} \\
(0.015)\end{array}$ \\
\hline Master's degree & $\begin{array}{l}0.291^{* * *} \\
(0.014)\end{array}$ & $\begin{array}{l}0.298^{* * *} \\
(0.014)\end{array}$ & $\begin{array}{l}0.267^{* * *} \\
(0.010)\end{array}$ & $\begin{array}{l}0.304^{* * *} \\
(0.012)\end{array}$ \\
\hline Bachelor's degree & $\begin{array}{l}0.186^{* * *} \\
(0.010)\end{array}$ & $\begin{array}{l}0.199 * * * \\
(0.011)\end{array}$ & $\begin{array}{l}0.188^{* * *} \\
(0.008)\end{array}$ & $\begin{array}{c}0.224^{* * *} \\
(0.010)\end{array}$ \\
\hline Some college & $\begin{array}{l}0.050^{* * *} \\
(0.012)\end{array}$ & $\begin{array}{l}0.062^{* * *} \\
(0.013)\end{array}$ & $\begin{array}{l}0.035^{* * *} \\
(0.011)\end{array}$ & $\begin{array}{l}0.074^{* * *} \\
(0.013)\end{array}$ \\
\hline Firm-specific IT experience & $\begin{array}{l}0.021^{* * *} \\
(0.002)\end{array}$ & $\begin{array}{l}0.023^{* * *} \\
(0.002)\end{array}$ & $\begin{array}{l}0.026^{* * *} \\
(0.002)\end{array}$ & $\begin{array}{l}0.023^{* * *} \\
(0.002)\end{array}$ \\
\hline General IT experience & $\begin{array}{c}0.039^{* * *} \\
(0.001)\end{array}$ & $\begin{array}{l}0.039^{* * *} \\
(0.002)\end{array}$ & $\begin{array}{l}0.036^{* * *} \\
(0.001)\end{array}$ & $\begin{array}{l}0.033^{* * *} \\
(0.001)\end{array}$ \\
\hline Total experience & $\begin{array}{c}-0.001 \\
(0.001)\end{array}$ & $\begin{array}{c}-0.000 \\
(0.001)\end{array}$ & $\begin{array}{c}0.000 \\
(0.000)\end{array}$ & $\begin{array}{c}-0.000 \\
(0.001)\end{array}$ \\
\hline Male & $\begin{array}{l}0.079 * * * \\
(0.010)\end{array}$ & $\begin{array}{c}0.082^{* * *} \\
(0.011)\end{array}$ & $\begin{array}{l}0.079 * * * \\
(0.008)\end{array}$ & $\begin{array}{l}0.083^{* * *} \\
(0.009)\end{array}$ \\
\hline Firm size & $\begin{array}{l}0.058^{* * *} \\
(0.004)\end{array}$ & $\begin{array}{l}0.042^{* * *} \\
(0.004)\end{array}$ & $\begin{array}{l}0.052^{* * *} \\
(0.003)\end{array}$ & $\begin{array}{l}0.048^{* * *} \\
(0.003)\end{array}$ \\
\hline Nonprofit and govt. sector & $\begin{array}{c}-0.050^{* * *} \\
(0.012)\end{array}$ & $\begin{array}{c}-0.040^{* * *} \\
(0.013)\end{array}$ & $\begin{array}{c}-0.056^{* * *} \\
(0.009)\end{array}$ & $\begin{array}{c}-0.062^{* * *} \\
(0.011)\end{array}$ \\
\hline IT industry & $\begin{array}{l}0.037^{* * *} \\
(0.010)\end{array}$ & $\begin{array}{l}0.033^{* * *} \\
(0.011)\end{array}$ & $\begin{array}{l}0.026^{* * *} \\
(0.009)\end{array}$ & $\begin{array}{c}0.016 \\
(0.010)\end{array}$ \\
\hline Dot-com firm & $\begin{array}{l}0.155^{* * *} \\
(0.017)\end{array}$ & $\begin{array}{c}0.026 \\
(0.017)\end{array}$ & $\begin{array}{l}0.084^{* * *} \\
(0.018)\end{array}$ & $\begin{array}{l}0.120^{* * * *} \\
(0.021)\end{array}$ \\
\hline IT-intensive industry & $\begin{array}{l}0.139 * * * \\
(0.010)\end{array}$ & $\begin{array}{l}0.136^{* * *} \\
(0.010)\end{array}$ & $\begin{array}{l}0.089^{* * *} \\
(0.008)\end{array}$ & $\begin{array}{l}0.086^{* * * *} \\
(0.008)\end{array}$ \\
\hline $\begin{array}{l}\text { Observations } \\
R \text {-squared }\end{array}$ & $\begin{array}{c}9,217 \\
0.394\end{array}$ & $\begin{array}{l}7,693 \\
0.379\end{array}$ & $\begin{array}{l}12,820 \\
0.373\end{array}$ & $\begin{array}{c}9,816 \\
0.362\end{array}$ \\
\hline F statistic & $290.09^{* * * *}$ & $237.95^{* * *}$ & $384.90^{* * * *}$ & $283.63^{* * *}$ \\
\hline df & 9,197 & 7,673 & 12,800 & 9,796 \\
\hline
\end{tabular}

Note. All the models use an intercept term, hours per week, and squared terms for IT experience at current firm and IT experience at other firms.

${ }^{*} p<0.1 ;{ }^{* * *} p<0.01$. Robust standard errors are in parentheses.

professionals. Second, our findings are not driven by failure to control for job titles. Other studies in labor economic literature do not control for job titles in wage regressions because doing so will understate returns on human capital (see, for example, Angrist and Krueger 1999, Krueger 1993). ${ }^{9}$ Nonetheless, salary

\footnotetext{
${ }^{9}$ For example, in the context of effect of computer use on wages, Krueger (1993, p. 39) specifically notes: "It is not clear whether occupation dummies are appropriate variables to include in these wage regressions because computer skills may enable workers to qualify for jobs in higher-paying occupations and industries."
}

Figure 4 Trends in Salary Premium by Visa and Citizenship Status

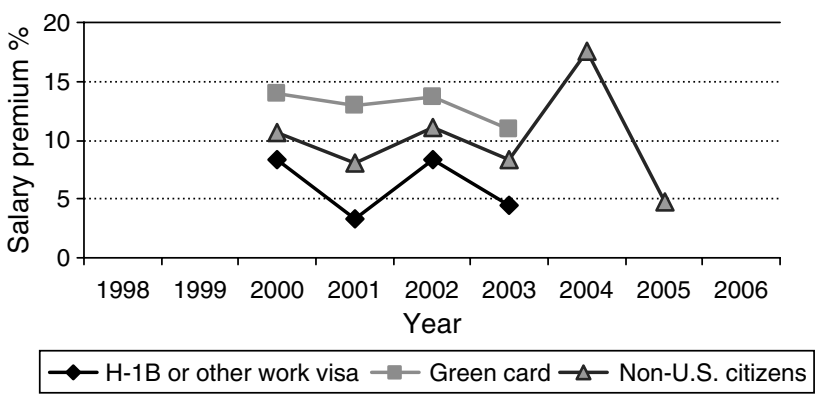

Note. Salary premium in this chart is calculated with respect to IT professionals with U.S. citizenship.

premiums decrease somewhat, but findings remain broadly similar even if we include job titles in wage regressions (see Table 8, column (3)). Third, because firms sometimes use IT professionals on contract (instead of as full-time employees), the part-time issue does not affect our findings because our sample uses data for full-time IT professionals only (excluding less than $1 \%$ contractors in the full sample). The use of total compensation in place of cash compensation also yields broadly similar results (see Table 8, column (4)).

Fourth, our findings related to returns on education are not driven by differences in variance on $e d u$ cation. Even though foreign IT workers have higher levels of education ( $42 \%$ of foreign IT professionals have master's degrees, and above compared to $23 \%$ in the case of U.S. citizens), because we use separate dummy variables for education variables, the variance of education variables for non-U.S. citizens is similar to or higher than that of education variables for U.S. citizens (see Table 2). Fifth, we also estimated our models using dummy indicators for firm size, instead of a continuous empno variable, and these models yielded essentially similar results to those we reported earlier. Sixth, because American IT professionals have higher mean levels of experience than the foreign workers, one may argue that the marginal value of an additional year of experience for U.S. IT workers is less. The reason is because U.S. IT workers are farther along the curve on concave wage-tenure profiles as shown in prior work (Slaughter et al. 2007). To rule out this alternative explanation, we computed marginal returns on IT experience at the mean level of total work experience in our data set and found that the relative magnitudes of returns on experience are essentially similar as reported earlier.

\footnotetext{
A parallel argument holds for our study in the sense that if immigration status is correlated with higher-paying job titles, then controlling for job titles can underestimate the salary premium associated with immigration status.
} 
Table 8 Summary of Key Results and Sensitivity Analyses

\begin{tabular}{|c|c|c|c|c|}
\hline & $\begin{array}{l}(1) \\
\text { Dependent variable is natural } \\
\text { log of cash compensation } \\
\text { (see Table 4, column (2)) }\end{array}$ & $\begin{array}{l}\text { (2) } \\
\text { Dependent variable is } \\
\text { natural log of cash } \\
\text { compensation }\end{array}$ & $\begin{array}{l}\text { (3) } \\
\text { Dependent variable is } \\
\text { natural log of cash } \\
\text { compensation }\end{array}$ & $\begin{array}{l}\text { (4) } \\
\text { Dependent variable is } \\
\text { natural log of total } \\
\text { compensation }\end{array}$ \\
\hline & $\begin{array}{l}\text { Without controls } \\
\text { for location and } \\
\quad \text { job titles }\end{array}$ & $\begin{array}{l}\text { With controls } \\
\text { for location } \\
\text { only }\end{array}$ & $\begin{array}{l}\text { With controls } \\
\text { for location } \\
\text { and job titles }\end{array}$ & $\begin{array}{l}\text { With controls } \\
\text { for location } \\
\text { and job titles }\end{array}$ \\
\hline \multicolumn{5}{|l|}{ Panel A } \\
\hline Non-U.S. citizen & $\begin{array}{l}0.085^{* * *} \\
(0.008)\end{array}$ & $\begin{array}{l}0.059^{* * * *} \\
(0.008)\end{array}$ & $\begin{array}{l}0.051^{* * *} \\
(0.007)\end{array}$ & $\begin{array}{l}0.059^{* * *} \\
(0.008)\end{array}$ \\
\hline \multicolumn{5}{|l|}{ Panel B } \\
\hline$H-1 B$ & $\begin{array}{l}0.066^{* * *} \\
(0.012)\end{array}$ & $\begin{array}{l}0.042^{* * *} \\
(0.012)\end{array}$ & $\begin{array}{l}0.026^{* *} \\
(0.013)\end{array}$ & $\begin{array}{c}0.026^{*} \\
(0.014)\end{array}$ \\
\hline Green card & $\begin{array}{l}0.122^{* * *} \\
(0.012)\end{array}$ & $\begin{array}{l}0.093^{* * *} \\
(0.012)\end{array}$ & $\begin{array}{l}0.078^{* * *} \\
(0.011)\end{array}$ & $\begin{array}{l}0.087^{* * *} \\
(0.013)\end{array}$ \\
\hline Capreached & $\begin{array}{l}0.038^{* * *} \\
(0.005)\end{array}$ & $\begin{array}{l}0.064^{* * *} \\
(0.005)\end{array}$ & $\begin{array}{l}0.037^{* * *} \\
(0.005)\end{array}$ & $\begin{array}{l}0.064^{* * *} \\
(0.005)\end{array}$ \\
\hline Capreached $\times$ green card & $\begin{array}{c}0.031 \\
(0.031)\end{array}$ & $\begin{array}{c}0.027 \\
(0.029)\end{array}$ & $\begin{array}{c}0.011 \\
(0.027)\end{array}$ & $\begin{array}{c}0.027 \\
(0.029)\end{array}$ \\
\hline Capreached $\times \mathrm{H}-1 \mathrm{~B}$ & $\begin{array}{c}0.055^{* *} \\
(0.026)\end{array}$ & $\begin{array}{c}0.058^{* *} \\
(0.025)\end{array}$ & $\begin{array}{c}0.039^{*} \\
(0.023)\end{array}$ & $\begin{array}{c}0.058^{* *} \\
(0.025)\end{array}$ \\
\hline
\end{tabular}

Notes. This table reports key coefficients of interest from regression models similar to the ones in Tables 4 and 5 . All the models include an intercept term, age, hours per week, and squared terms for IT experience at current firm and IT experience at other firms.

aWe control for location by including dummies for the U.S. states. We control for job titles by including dummies for titles. Respondents in our study have 35 job titles including supervisor, manager, program manager, project manager, senior manager, director, vice president, chief technology officer, chief information officer, analyst, architect, business analyst, database administrator, designer, e-business specialist, hardware engineer, help desk specialist, network engineer/technician, programmer, programmer/analyst, project leader, qa/software test engineer/analyst, sales support engineer, software developer, software engineer, systems programmer, systems analyst, systems architect, systems administrator, specialist, telecommunications specialist, Webmaster, Web developer, general IT staff, and a remaining category for "other" positions.

${ }^{*} p<0.1 ;{ }^{* *} p<0.05 ;{ }^{* * *} p<0.01$. Robust standard errors are in parentheses.

Finally, we used a propensity score matching approach to compute differences in wages of IT professionals due to citizenship and visa status (for further details on this approach, see Mithas et al. 2006, Mithas and Krishnan 2009, Rosenbaum and Rubin 1983). This approach compares compensation of non U.S. citizen or work visa IT professionals with that of comparable U.S. citizen IT professionals as in H1A, $\mathrm{H} 1 \mathrm{~B}$, or $\mathrm{H} 1 \mathrm{C}$, ensuring that that matched workers are similar on propensity scores based on their observed characteristics. The results of the propensity score analyses (see Figures A.1-A.3 in the online appendix showing propensity score matching across strata) suggest that IT professionals without U.S. citizenship earn approximately $8.1 \%$ more than those with U.S. citizenship, IT professionals on an $\mathrm{H}-1 \mathrm{~B}$ or other work visa earn approximately $7.9 \%$ more than those with U.S. citizenship, and IT professionals with a green card earn approximately $13.6 \%$ more than those with U.S. citizenship or work visa holders (see column (3) of Table 9). ${ }^{10}$ These results, in broad correspondence

${ }^{10}$ We thank Sandra Slaughter for suggesting the use of the propensity score approach. Additional details on the propensity score approach are available from the authors upon request. with the ones in Table 4, provide further confidence in the robustness of the main findings of this study.

The online appendix reports additional details on the representativeness of our sample and results of post hoc analyses.

\section{Discussion}

\subsection{Main Findings}

This study provides several new insights. First, we find that non-U.S. citizen IT professionals earn a significant salary premium when compared with IT professionals with U.S. citizenship, suggesting that American and foreign IT professionals are not perfect substitutes and may in fact be complements of each other. These findings may be a result of the unique human capital possessed by foreign IT professionals, consistent with the human capital- and expertise-based arguments in the theory section. Second, we find some evidence that restrictive visa policies and lower visa caps result in higher salary premiums for those with a work visa. Even in a relatively liberal visa regime during 2001 to 2003, IT professionals without U.S. citizenship and IT professionals 
Table 9 Overall Treatment Effect of Citizenship/Visa Status on Compensation Using Propensity Score Approach

\begin{tabular}{|c|c|c|c|}
\hline & $\begin{array}{c}\text { (1) } \\
\text { Natural log of } \\
\text { total compensation } \\
\text { in } 1999 \text { dollars for } \\
\text { treated subjects }\end{array}$ & $\begin{array}{c}\text { (2) } \\
\text { Natural log of } \\
\text { total compensation } \\
\text { in } 1999 \text { dollars for } \\
\text { controls subjects }\end{array}$ & $\begin{array}{c}(3) \\
\text { Difference in } \\
\text { natural log of } \\
\text { total compensation } \\
\text { in } 1999 \text { dollars }\end{array}$ \\
\hline \multicolumn{4}{|c|}{ Panel A: Effect of citizenship on compensation } \\
\hline & Non-U.S. citizens & U.S. citizens & \\
\hline Before matching & 11.233 & 11.115 & 0.118 \\
\hline After matching ${ }^{\mathrm{a}}$ & 11.233 & 11.152 & $0.081^{b}$ \\
\hline \multicolumn{4}{|c|}{ Panel B: Effect of work visa on compensation } \\
\hline & Work visa holders & U.S. citizens & \\
\hline Before matching & 11.227 & 11.121 & 0.105 \\
\hline After matching ${ }^{\mathrm{a}}$ & 11.227 & 11.149 & $0.079^{b}$ \\
\hline \multicolumn{4}{|c|}{ Panel C: Effect of citizenship on compensation } \\
\hline & Green card holders & $\begin{array}{l}\text { U.S. citizens and work } \\
\text { visa holders }\end{array}$ & \\
\hline Before matching & 11.270 & 11.127 & 0.143 \\
\hline After matching ${ }^{\mathrm{a}}$ & 11.270 & 11.134 & $0.136^{b}$ \\
\hline
\end{tabular}

on $\mathrm{H}-1 \mathrm{~B}$ or other work visas enjoyed salary premiums, suggesting that the case for visa policies of the past having adversely affected U.S. citizens may be overstated.

Third, the results suggest that returns on education are generally higher for U.S. citizens, whereas returns on IT experience are higher for non-U.S. citizens. Furthermore, firms pay a significant premium for IT experience at other firms compared to IT experience at the current firm of U.S. citizens. However, for non-U.S. citizens, firms do not value IT experience at other firms compared to IT experience at the current firm. Note also that U.S. citizens are likely to acquire almost all of their IT experience working with firms in the United States, whereas non-U.S. citizens may have acquired some IT experience, particularly the IT experience at other firms, working outside the United States. Although our data do not allow us to know how much of the IT experience was acquired outside the United States, it may be that firms value IT experience acquired outside the United States less than they value the IT experience within the United States (Duleep and Regets 1999, Friedberg 2000).

These findings should be of interest to researchers interested in issues related to high-skill immigration, and being contrary to the popular beliefs, they should interest practitioners because they respond to the call by Grover et al. $(2008$, p. 46) to look for new patterns in data to "seek contradictions... or what surprises practitioners."

\subsection{Implications for Research}

We note four important research implications of our study. First, the finding that firms place a premium on human capital of non-U.S. citizens and work visa holders suggests that intangible human capital associated with immigration and willingness to work in a foreign country is valued by employers. There is a need for further research to understand the more disaggregated dimensions of intangible human capital because of its growing importance in an increasingly "flatter" world that requires IT professionals to become adept at managing across different cultural and business contexts. There is also a need to understand how American professionals can be equipped with requisite skills to make them more competitive in U.S. and international labor markets. Although many U.S. universities now recognize the importance of imparting an appreciation of foreign cultures through study abroad programs, the efficacy and economic benefits of such programs for those who participate in them is a fruitful area of research.

Second, our study shows that, on the whole, foreign IT professionals are complements of American IT professionals. Understanding how this complementarity directly benefits firms in terms of improved productivity and innovation capacity will help to explain further why firms value foreign IT professionals. Such studies will also enrich the business value of IT literature which, to date, has focused mostly on IT technology artifacts without considering the unique roles 
of foreign and American IT professionals in the production function. To the extent supply of high-skill foreign IT professionals in the U.S. economy might induce skill-biased technical change (Acemoglu 1998), they not only benefit American professionals with whom they are complements by increasing the skill premium for all IT professionals, but they also create spillover effects in upstream and downstream sectors of the economy. There is a need for further studies to understand the impact of foreign IT professionals and these spillover effects.

Third, this study has focused on the wage differences, if any, among IT professionals of varying visa and citizenship statuses working in the United States and the role of visa and immigration policies in such wage differences. However, wages capture only one dimension of the labor market. Visa and immigration policies have likely affected U.S. citizens' impressions of the IT job market and decisions of college students and others to enter into IT careers. There is a need to study these other effects of visa and immigration policies that can potentially reduce the supply of U.S. citizen IT professionals.

Finally, although this study fails to find evidence for foreign professionals earning less than American professionals and, on the contrary, finds evidence for salary premium for foreign professionals, the extent to which this premium impacts their compensation satisfaction or job satisfaction remains to be examined. There is a need for further studies to compare American IT professionals with foreign IT professionals along such dimensions to understand the fundamental differences in their aspirations and expectations. The results should help to design appropriate human resource policies to motivate and retain them. Lacity et al. (2008) provide a useful framework for undertaking such studies.

\subsection{Implications for Practice}

Our findings have important policy and managerial implications. From a policy perspective, this study suggests that, contrary to popular belief, non-U.S. citizen IT professionals are not paid less compared to American IT professionals. More broadly, the evidence in this study provides indirect evidence that visa and immigration policies so far have not had any adverse impact on the wages of American IT professionals due to any relatively lower compensation of foreign IT professionals. Comparisons of average salaries or those based on the compensation information in LCA petitions, which do not adequately adjust for educational qualifications, work experience, or institutional factors associated with American or foreign professionals, can lead to wrong conclusions. The current study, using actual salary data from IT professionals, suggests that calls for making visa policies more restrictive to protect American professionals and to prevent exploitation of foreign professionals need to be examined more carefully. Although some instances of potential abuse can not be ruled out for any policy, an appropriate and prudent policy response for any allegations of visa abuse should be commensurate with the seriousness of the actual abuse. Setting visa caps higher is perhaps less damaging than setting them too low because, if the economy does not need foreign professionals, then these visa caps will remain underutilized, as happened from 2001-2003. On the other hand, policies that restrict the supply of highly skilled professionals for U.S. firms may force U.S. companies to hire professionals overseas, thus defeating the very rationale invoked for reactive policy responses (Lewin et al. 2009, Thibodeau 2008). This phenomenon may already be occurring because the number of IT professionals hired by companies like IBM and Accenture in India in recent times far exceeds the number of IT professionals with $\mathrm{H}-1 \mathrm{~B}$ or other work visas on their payroll. ${ }^{11}$ By the end of 2007, IBM had more than 70,000 employees in India, and Accenture was slated to have more employees in India than in the United States (Giridhardas 2007). More importantly, restrictive visa policies, to the extent they lead to reverse migration and thus potential loss of skills, innovation, and entrepreneurship of foreign-born IT professionals, particularly those who acquired higher education in U.S. universities (Wadhwa 2009), can also hurt the long-term competitiveness of U.S. firms and the U.S. economy.

From a managerial perspective, our findings suggest that managers should not treat foreign and American IT professionals as substitutes, and can benefit from their complementary skills to create new products and services for global markets. A culturally and globally diverse workforce, even if it comes at a higher price and means paying higher wages for foreign IT professionals, may prove highly effective in capitalizing on opportunities for leveraging foreign countries as source or as markets for improved competitiveness.

From the perspective of an individual knowledge worker, our results suggest that IT jobs continue to offer salary premiums to those who possess the skills needed by firms in a global economy. Although IT jobs being information intensive are more amenable to offshoring (Apte and Mason 1995), this study should set to rest the pessimism in the media

\footnotetext{
${ }^{11}$ The increased hiring in India is not due to visa policies of the United States alone but is also driven by other economic factors such as the availability of a high-quality talent pool at a lower cost and the need to serve customers located across the globe in different time zones.
} 
about the dim prospects for all IT jobs. As other research studies report, on average, high-informationintensive occupations did not experience a decline in employment or salary growth until 2005. In addition high-information-intensity occupations experienced greater salary growth than occupations with a higher need for physical presence (Mithas and Whitaker 2007). Indeed, high-information-intensity and high-skill occupations experienced high employment growth until 2005. Our study suggests that U.S. IT professionals will benefit by proactively making investments in their human capital by acquiring business and behavioral skills that are in demand in the emerging service economy (Mithas and Krishnan 2008, Mithas and Whitaker 2007, Ramasubbu et al. 2008a). Like other knowledge workers, IT professionals must make continuous investment in their skills and upgrade their human capital to benefit from global service disaggregation while avoiding any potential negative impact to their own employment prospects or wages.

To conclude, this study examines the effect of visa and immigration policies on compensation of IT professionals working in the United States. We find that IT professionals on $\mathrm{H}-1 \mathrm{~B}$ or other work visas earn a significant salary premium when compared with IT professionals with U.S. citizenship. This result implies complementarity among American and foreign IT professionals and supports the view that high-skill immigration can potentially make everyone (i.e., American as well as foreign workers) better off (Saxenian 2002). There is some evidence that salary premiums for those with work visas respond to visa and immigration policies and that restrictive visa policies may result in higher salary premiums. Because IT professionals and other knowledge workers are a critical resource for innovation, these findings have important implications for developing informed visa and immigration policies for these professionals.

\section{Electronic Companion}

An electronic companion to this paper is available as part of the online version that can be found at http:// mansci.journal.informs.org/.

\section{Acknowledgments}

The authors thank Ron Hira, Natalia Levina, Oliver Lin, Norman Matloff, Prasanna Tambe, Bruce Weber, Jonathan Whitaker, Madeline Zavodny, and the participants of the NYU 2008 conference on Global Delivery of Professional Services, the CIST-INFORMS 2008 conference in Washington DC, the WISE 2008 conference in Paris, and the Sloan Industry Studies 2009 conference in Chicago for helpful discussions and comments on previous versions of this paper.

\section{References}

Acemoglu, D. 1998. Why do new technologies complement skills? Directed technical change and wage inequality. Quart. J. Econom. 113(4) 1055-1089.

Aeppel, T. 2007. Overseas profits provide shelter for U.S. firms. Wall Street Journal (August 9) A1.

Agarwal, R., T. W. Ferratt. 1999. Coping with Labor Scarcity in Information Technology: Strategies and Practices for Effective Recruitment and Retention. Pinnaflex, Cincinnati.

Agtmael, A. v. 2007. The Emerging Markets Century. Free Press, New York.

Ang, S., S. A. Slaughter. 2000. The missing context of information technology personnel: A review and future directions for research. R. W. Zmud, ed. Framing the Domains of IT Management: Projecting the Future Through the Past. Pinnaflex Press, Cincinnati, 305-327.

Ang, S., S. A. Slaughter, K. Y. Ng. 2002. Human capital and institutional determinants of information technology compensation: Modeling multilevel and cross-level interactions. Management Sci. 48(11) 1427-1445.

Angrist, J. D., A. B. Krueger. 1999. Empirical strategies in labor economics. O. Ashenfelter, D. Card, eds. Handbook of Labor Economics. Elsevier, Amsterdam, 1277-1366.

Apte, U. M., R. O. Mason. 1995. Global disaggregation of information-intensive services. Management Sci. 41(7) 1250-1262.

Apte, U. M., U. S. Karmarkar, H. K. Nath. 2008. Information services in the U.S. economy: Value, jobs, and management implications. California Management Rev. 50(3) 12-30.

Bartol, K. M., W. Aspray. 2006. The transition of women from academic world to the IT workplace: A review of the relevant research. J. M. Cohoon, W. Aspray, eds. Women and Information Technology. MIT Press, Cambridge, MA, 377-419.

Becker, G. S. 1993. Human Capital: A Theoretical and Empirical Analysis with Special Reference to Education. University of Chicago Press, Chicago.

Bhagwati, J. 2004. In Defense of Globalization. Oxford University Press, Oxford, UK.

Bharadwaj, A. S., S. G. Bharadwaj, B. R. Konsynski. 1999. Information technology effects on firm performance as measured by Tobin's q. Management Sci. 45(7) 1008-1024.

Boh, W. F., Y. Ren, S. Kiesler, R. Bussjaeger. 2007. Expertise and collaboration in the geographically dispersed organization. Organ. Sci. 18(4) 595-612.

Borjas, G. J. 1987. Self-selection and the earnings of immigrants. Amer. Econom. Rev. 77(4) 531-553.

Borjas, G. J. 1989. Economic theory and international migration. Internat. Migration Rev. 23(3) 457-485.

Borjas, G. J. 1994. The economics of lmmigration. J. Econom. Literature 32(4) 1667-1717.

Borjas, G. J. 2001. Heaven's Door. Princeton University Press, Princeton, NJ.

Borjas, G. J. 2003. The labor demand curve is downward sloping: Reexamining the impact of immigration on the labor market. Quart. J. Econom. 118(4) 1335-1374.

Borjas, G. J. 2005. The labor-market impact of high-skill immigration. Amer. Econom. Rev. 95(2) 56-60.

Borjas, G. J., M. Tienda. 1987. The economic consequences of immigration. Science 235(4789) 645-651.

Butcher, K. F., D. Card. 1991. Immigration and wages: Evidence from the 1980s. Amer. Econom. Rev. 81(2) 292-296.

Card, D. 1990. The impact of the Mariel Boatlift on the Miami labor market. Indust. Labor Relations Rev. 43(2) 245-257.

Card, D. 2001. Immigrant inflows, native outflows, and the local labor market impacts of higher immigration. J. Labor Econom. 19(1) 22-64. 
Carmel, E., R. Agarwal. 2002. The maturation of offshore sourcing of information technology work. MIS Quart. Executive 1(2) 65-77.

Chellaraj, G., K. E. Maskus, A. Mattoo. 2005. The contribution of skilled immigration and international graduate students to U.S. innovation. Working paper 3588, World Bank Policy Research, World Bank, Washington, DC.

Chiswick, B. R. 1978. The effect of Americanization on the earnings of foreign-born men. J. Political Econom. 86(5) 897-921.

Constable, P. 2007. Worker visas intensify debate on immigration. Washington Post (May 25) A01.

Davis, G. B., P. Ein-Dor, W. R. King, R. Torkzadeh. 2006. IT offshoring: History, prospects and challenges. J. Assoc. Inform. Systems 7(11) 770-795.

DiRomulado, A., V. Gurbaxani. 1998. Strategic intent for IT outsourcing. Sloan Management Rev. 39(4) 67-80.

Duleep, H. O., M. C. Regets. 1999. Immigrants and human-capital investment. Amer. Econom. Rev. 89(2) 186-191.

Economist, The. 2009. Magic formula: The secrets of entrepreneurial success (A special report on entrepreneurship). (March 14) $17-18$.

Espinosa, J. A., W. DeLone, G. Lee. 2006. Global boundaries, task processes and IS project success: A field study. Inform. Tech. People 19(4) 345-370.

Espinosa, J. A., S. A. Slaughter, R. E. Kraut, J. D. Herbsleb. 2007. Familiarity, complexity, and team performance in geographically distributed software development. Organ. Sci. 18(4) 613-630.

Ferratt, T. W., R. Agarwal, C. V. Brown, J. E. Moore. 2005. IT human resource management configurations and IT turnover: Theoretical synthesis and empirical analysis. Inform. Systems Res. 16(3) 237-255.

Freeman, R. B. 2006. People flows in globalization. J. Econom. Perspective 20(2) 145-170.

Friedberg, R. M. 2000. You can't take it with you? Immigrant assimilation and the portability of human capital. J. Labor Econom. 18 221-251.

Friedberg, R. M. 2001. The impact of mass migration on the Israeli labor market. Quart. J. Econom. 116 1373-1408.

Friedberg, R. M. 2007. The economic impact of knowledge workers from India and China. U. Tambar, ed. Movement of Global Talent: The Impact of High Skill Labor Flows from India and China. Princeton University, Princeton, NJ, 35-53.

Friedberg, R. M., J. Hunt. 1995. The impact of immigrants on host country wages, employment and growth. J. Econom. Perspectives 9(2) 23-44.

Giridhardas, A. 2007. India's edge goes beyond outsourcing. New York Times (April 4), http://www.nytimes.com/2007/ 04/04/business/worldbusiness/04rupee.html.

Grover, V., K. Lyytinen, A. Srinivasan, B. C. Y. Tan. 2008. Contributing to rigorous and forward thinking explanatory theory. J. Assoc. Inform. Systems 9(2) 40-47.

Gupta, A. K., H. Wang. 2009. Getting China and India Right: Strategies for Leveraging the World's Fastest-Growing Economies for Global Advantage. Jossey-Bass, San Francisco.

Gurcak, J. C., T. J. Espenshade, A. Sparrow, M. Paskoff. 2001. Immigration of scientists and engineers to the United States: Issues and evidence. W. A. Cornelius, T. J. Espenshade, I. Salehyan, eds. The International Migration of the Highly Skilled. Center for the comparative immigration studies, University of California, San Diego.

Han, K., R. J. Kauffman, B. R. Nault. 2010. Returns to information technology outsourcing. Inform. Systems Res. Forthcoming.

Hari, P. 2009. Protectionist attitudes. Businessworld (March 9) 52-53.

Harter, D. E., S. A. Slaughter. 2003. Quality improvement and infrastructure activity costs in software development: A longitudinal analysis. Management Sci. 49(6) 784-800.
Herbst, M. 2008. Are H1-B workers getting bilked? Bus. Week (February 11) 57-59.

Hira, R. 2004. U.S. immigration regulations and India's information technology industry. Tech. Forecasting Soc. Change 71 837-854.

Hirschheim, R., C. Loebbecke, M. Newman, J. Valor. 2007. Offshoring and its implications for the information systems discipline: Where perception meets reality. Comm. Assoc. Inform. Systems (20, Article 51) 1-22.

Hunt, J. 1992. The impact of the 1962 repatriates from Algeria on the French labor market. Indust. Labor Relations Rev. 45 556-572.

Hunt, J., Gauthier-Loiselle. 2009. How much does immigration boost innovation?. Working paper, McGill University, Vancouver.

Ipsen, E. 1994. Expatriates: Off the gravy train. New York Times (June 8), http://www.nytimes.com/1994/06/08/business/ worldbusiness /08iht-expats.html?pagewanted $=1$.

Ives, B., S. L. Jarvenpaa. 1991. Applications of global information technology: Key issues for management. MIS Quart. 15(1) 33-49.

Jarvenpaa, S. L., B. Ives. 1993. Organizing for global competition: The fit of information technology. Decision Sci. 24(3) 547-580.

Josefek, R. A. J., R. J. Kauffman. 2003. Nearing the threshold: An economics approach to pressure on information systems professionals to separate from their employer. J. Management Inform. Systems 20(1) 87-122.

Kerr, W. R., W. F. Lincoln. 2010. The supply side of innovation: $\mathrm{H}-1 \mathrm{~B}$ visa reforms and US ethnic invention. J. Labor Econom. Forthcoming.

King, W. R., G. Torkzadeh. 2008. Information systems offshoring: Research status and issues. MIS Quart. 32(2) 205-225.

Krishna, S., S. Sahay, G. Walsham. 2004. Managing cross-cultural issues in global software outsourcing. Comm. ACM 47(4) 62-66.

Krueger, A. B. 1993. How computers have changed the wage structure: Evidence from microdata, 1984-1989. Quart. J. Econom. 108(1) 33-60.

Lacity, M. C., D. F. Feeny, L. P. Willcocks. 2003. Transforming a backoffice function: Lessons from BAE systems' experience with an enterprise partnership. MIS Quart. Executive 2(2) 86-103.

Lacity, M. C., V. V. Iyer, P. S. Rudramuniyaiah. 2008. Turnover intentions of Indian IS professionals. Inform. Systems Frontiers $\mathbf{1 0}$ 225-241.

LaLonde, R. J., R. Topel. 1991. Labor market adjustments to increased immigration. J. Abowd, R. Freeman, eds. Immigration, Trade and the Labor Market. University of Chicago Press, Chicago, 167-200.

Levina, N., A. A. Kane. 2009. Onshore immigrant managers as boundary spanners on offshored software development projects: Partners or bosses? Working paper, Stern School of Business, New York University, New York.

Levina, N., M. Xin. 2007. Comparing IT workers' compensation across country contexts: Demographic, human capital, and institutional factors. Inform. System Res. 18(2) 193-210.

Lewin, A. Y., S. Massini, C. Peeters. 2009. Why are companies offshoring innovation? The emerging global race for talent. J. Internat. Bus. Stud. 40 901-925.

Lowell, B. L. 2001. The foreign temporary workforce and shortages in information technology. W. A. Cornelius, T. J. Espenshade, I. Salehyan, eds. The International Migration of the Highly Skilled: Demand, Supply, and Development Consequences in Sending and Receiving Countries. Center for the comparative immigration studies, University of California, San Diego.

Lowell, L. 2007. Federal immigration policies and the movement of Chinese and Indian knowledge workers to and from the United States. U. Tambar, ed. Movement of Global Talent: The Impact of High Skill Labor Flows from India and China. Princeton University, Princeton, NJ, 89-105. 
Matloff, N. 2003. On the need for reform of the H-1B nonimmigrant work visa in computer-related occupations. Univ. Michigan J. Law Reform 36(4) 815-914.

Matloff, N. 2004. Globalization and the American IT worker. Comm. ACM 47(11) 27-29.

McGee, M. K. 2006. No escaping H-1B. InformationWeek (June 12) $40-48$.

Miano, J. The Bottom of the Pay Scale: Wages for H-1B Computer Programmers. Center for Immigration Studies, Washington, DC, $1-11$

Mithas, S. 2008. Are emerging markets different from developed markets? Human capital sorting and segmentation in compensation of information technology professionals. Proc. 29th Internat. Conf. on Inform. Systems, Association for Information Systems, Paris.

Mithas, S., M. S. Krishnan. 2008. Human capital and institutional effects in the compensation of information technology professionals in the United States. Management Sci. 54(3) 415-428.

Mithas, S., M. S. Krishnan. 2009. From association to causation via a potential outcomes approach. Informat. Systems Res. 20(2) 295-313.

Mithas, S., J. Whitaker. 2007. Is the world flat or spiky? Information intensity, skills and global service disaggregation. Inform. Systems Res. 18(3) 237-259.

Mithas, S., J. W. Whitaker. 2009. Information technology and globalization: Theory and evidence. Proc. 14th Annual INFORMS Conf. Inform. Systems Tech., Information Systems Society, San Diego.

Mithas, S., D. Almirall, M. S. Krishnan. 2006. Do CRM systems cause one-to-one marketing effectiveness? Statist. Sci. 21(2) 223-233.

Mittal, N., B. R. Nault. 2009. Investments in information technology: Indirect effects and information technology intensity. Inform. Systems Res. 20(1) 140-154.

National Research Council. 2001. Building a Workforce for the Information Economy. National Academy Press, Washington, DC.

National Foundation for American Policy (NFAP). 2007. Driving jobs and innovation offshore: The impact of high-skill immigration restrictions on America. National Foundation for American Policy, Washington, DC, 1-37.

National Foundation for American Policy (NFAP). 2008. H-1B visas and job creation. National Foundation for American Policy, Washington, DC, 1-19.

Oettl, A., A. Agrawal. 2008. International labor mobility and knowledge flow externalities. J. Internat. Bus. Stud. 39 1242-1260.

Orrenius, P. M., M. Zavodny. 2007. Does immigration affect wages? A look at occupation-level evidence. Labour Econom. 14 757-773.

Oshri, I., J. Kotlarsky, L. Willcocks. 2007. Managing dispersed expertise in IT offshore outsourcing: Lessons from tata consultancy services. MIS Quart. Executive 6(2) 53-65.

Park, E. J. W. 2007. Unworthy of a nation built by immigrants: The political mobilization of $\mathrm{H}-1 \mathrm{~B}$ workers. U. Tambar, ed. Movement of Global Talent: The Impact of High Skill Labor Flows from India and China. Princeton University, Princeton, NJ, 75-88.

Rai, A., R. Patnayakuni, N. Patnayakuni. 1997. Technology investment and business performance. Comm. ACM 40(7) 89-97.

Ramasubbu, N., S. Mithas, M. S. Krishnan. 2008a. High tech, high touch: The effect of employee skills and customer heterogene- ity on customer satisfaction with enterprise system support services. Decision Support Systems 44(2) 509-523.

Ramasubbu, N., S. Mithas, M. S. Krishnan, C. F. Kemerer. 2008b. Work dispersion, process-based learning and offshore software development performance. MIS Quart. 32(2) 437-458.

Rodrik, D. 1997. Has Globalization Gone Too Far? Institute for International Economics, Washington, DC.

Roman, D. 2006. Analysis: H-1B pay drags down all salaries. EE Times (June 19), http://www.informationweek.com/story/ showArticle.jhtml?articleID=189500671.

Rosenbaum, P. R., D. B. Rubin. 1983. The central role of the propensity score in observational studies for causal effects. Biometrika 70(1) 41-55.

Rottman, J. W., M. C. Lacity. 2004. Twenty practices for offshore sourcing. MIS Quart. Executive 3(3) 117-130.

Santhanam, R., E. Hartono. 2003. Issues in linking information technology capability to firm performance. MIS Quart. 27(1) $125-153$.

Saxenian, A. 2002. Brain circulation: How high-skill immigration makes everyone better off? Brookings Rev. 20(1) 28-31.

Schultz, T. W. 1961. Investments in human capital. Amer. Econom. Rev. 51(1) 1-17.

Singh, S. 2003. U.S. visas are not a TCS-specific issue. Businessworld (India) (June) 1.

Slaughter, S. A., S. Ang, W. F. Boh. 2007. Firm-specific human capital and compensation-organizational tenure profiles: An archival analysis of salary data for IT professionals. Human Resource Management 46(3) 373-394.

Tambe, P. B., L. M. Hitt. 2008. H-1B Visas, offshoring, and the labor market outcomes of US information technology workers. Working paper, Stern School of Business, New York University, New York.

Thibodeau, P. 2008. Gates: U.S. puts tech jobs at risk by capping foreign workers. Computerworld (March 12), http:// www.computerworld.com/action/article.do?command=view ArticleBasic\&articleId $=9068126$.

Thibodeau, P. 2009. Microsoft to hire H-1B workers, even as it lays off some visa holders. Computerworld (March 4), http://www. computerworld.com/s/article/9128962/Microsoft_to_hire_H_ 1B_workers_even_as_it_lays_off_some_visa_holders.

Truman, G. E., J. J. Baroudi. 1994. Gender differences in the information systems managerial ranks: An assessment of potential discriminatory practices. MIS Quart. 18(2) 129-142.

U.S. Department of Commerce. 1997. America's new deficit: The shortage of information technology workers. Accessed March 8, 2010, http://www.eric.ed.gov/ERICDocs/data/ ericdocs2sql/content_storage_01/0000019b/80/14/ff/a4.pdf.

U.S. Citizenship and Immigration Services (USCIS). 2007. I am an employer: How do I hire a foreign national for shortterm employment in the United States? Guide for employers M-582 (01/07), U.S. Citizenship and Immigration Services, Washington, DC.

Wadhwa, V. 2009. America's immigrant brain drain. Bus. Week (March 16) 068.

Whoriskey, P. 2008. Skilled-worker visa demand expected to far exceed supply. Washington Post (April 1) D3.

Zavodny, M. 2003. The H-1B program and its effects on information technology workers. Federal Reserve Bank of Atlanta Econom. Rev. (Third Quarter) 1-11. 